\title{
Virus-producing cells determine the host protein profiles of HIV-1 virion cores
}

\author{
Steven Santos ${ }^{1}$, Yuri Obukhov ${ }^{2,3}$, Sergei Nekhai ${ }^{2,3}$, Michael Bukrinsky ${ }^{1}$ and Sergey lordanskiy ${ }^{1 *}$
}

\begin{abstract}
Background: Upon HIV entry into target cells, viral cores are released and rearranged into reverse transcription complexes (RTCs), which support reverse transcription and also protect and transport viral CDNA to the site of integration. RTCs are composed of viral and cellular proteins that originate from both target and producer cells, the latter entering the target cell within the viral core. However, the proteome of HIV-1 viral cores in the context of the type of producer cells has not yet been characterized.

Results: We examined the proteomic profiles of the cores purified from HIV-1 NL4-3 virions assembled in Sup-T1 cells (T lymphocytes), PMA and vitamin $\mathrm{D}_{3}$ activated THP1 (model of macrophages, $\mathrm{mM} \Phi$ ), and non-activated THP1 cells (model of monocytes, mMN) and assessed potential involvement of identified proteins in the early stages of infection using gene ontology information and data from genome-wide screens on proteins important for HIV-1 replication. We identified 202 cellular proteins incorporated in the viral cores (T cells: 125, mMФ: 110, mMN: 90) with the overlap between these sets limited to 42 proteins. The groups of RNA binding (29), DNA binding (17), cytoskeleton (15), cytoskeleton regulation (21), chaperone (18), vesicular trafficking-associated (12) and ubiquitinproteasome pathway-associated proteins (9) were most numerous. Cores of the virions from SupT1 cells contained twice as many RNA binding proteins as cores of THP1-derived virus, whereas cores of virions from $\mathrm{mM \Phi}$ and $\mathrm{mMN}$ were enriched in components of cytoskeleton and vesicular transport machinery, most probably due to differences in virion assembly pathways between these cells. Spectra of chaperones, cytoskeletal proteins and ubiquitinproteasome pathway components were similar between viral cores from different cell types, whereas DNA-binding and especially RNA-binding proteins were highly diverse. Western blot analysis showed that within the group of overlapping proteins, the level of incorporation of some RNA binding (RHA and HELIC2) and DNA binding proteins (MCM5 and Ku80) in the viral cores from T cells was higher than in the cores from both $\mathrm{mM} \Phi$ and $\mathrm{mMN}$ and did not correlate with the abundance of these proteins in virus producing cells.

Conclusions: Profiles of host proteins packaged in the cores of HIV-1 virions depend on the type of virus producing cell. The pool of proteins present in the cores of all virions is likely to contain factors important for viral functions. Incorporation ratio of certain RNA- and DNA-binding proteins suggests their more efficient, non-random packaging into virions in $T$ cells than in $\mathrm{mM} \Phi$ and $\mathrm{mMN}$.
\end{abstract}

\section{Background}

HIV-1 viral particles released from infected cells have been shown to incorporate many cellular proteins during the assembly and budding steps of morphogenesis. Findings from earlier studies, summarized in a web-based database (http://web.ncifcrf.gov/research/avp/protein_db.

\footnotetext{
* Correspondence: siord@gwu.edu

'Department of Microbiology, Immunology and Tropical Medicine, George Washington University School of Medicine and Health Sciences, 2300 I Street NW, Ross Hall, Washington, DC 20037, USA

Full list of author information is available at the end of the article
}

asp), identified more than three hundred cellular proteins in HIV-1 particles. HIV-1, as well as other lentiviruses, incorporates components of the cellular endosomal sorting machinery and cytoskeleton proteins involved in the process of particle assembly [1-5], surface proteins captured with the plasma membrane during budding [6,7], RNA-binding proteins associated with incorporated viral RNA and RNA-Gag complexes [4,8-10], chaperones [11], and multiple concomitant proteins (reviewed in [12]) whose functions in viral morphogenesis and infectivity are still unknown.

\section{Biomed Central}


Upon fusion of an HIV-1 particle with a target cell, viral cores are released into the cytoplasm and rearranged into sub-viral particles called reverse transcription complexes (RTCs), which subsequently mature into pre-integration complexes (PICs). These nucleoprotein structures support reverse transcription and also protect and transport viral cDNA to the site of integration. RTCs are composed of both viral and cellular proteins. Since RTCs are formed from the viral cores, their initial composition is identical to that of viral cores. Other than the key enzymatic components, reverse transcriptase (RT) and integrase (IN), at least five other viral proteins involved in structural organization, cytoplasmic trafficking and nuclear import (matrix [MA], nucleocapsid $[\mathrm{NC}]$, capsid [CA], Nef and viral protein $\mathrm{R}[\mathrm{Vpr}])$, have been identified as components of HIV-1 RTCs [13-19], reviewed in [20-22].

Although the key early steps of HIV replication, reverse transcription and integration, are relatively autonomic, the participation of cellular proteins in early infection events has been demonstrated in previous studies [23-25]. After release from the viral particles, RTCs are still encapsulated in the shells formed by p $24^{\mathrm{CA}}$ molecules which are stable in the cytoplasm for at least several hours [26,27]. The shell is believed to protect the reverse transcription machinery and all encapsulated proteins from the cytoplasmic environment to provide optimal conditions for their functional activity [28] and may contribute to the nuclear import of PICs [19,29-31]. The shell likely limits the access of host cell proteins to the RTC interior. Thus, most cellular factors which may contribute to the functional competence of early RTCs should be expected to get into the complexes from the cores of infecting virions.

The cellular proteins, which are known to be hijacked by assembling virus particles from virus-producing cells and are involved in the early post-entry stages of HIV-1 infection, can be grouped into the following categories. (1) Factors involved in the spatial organization and correct folding of viral proteins in the virion and probably RTC: clathrin [5,32] and heat shock proteins (Hsp70, Hsc70, Hsp60) [11,33] are probably critical for spatial organization of Gag and Pol proteins and regulation of proteolytic processing and folding of the Pol products RT and integrase; thioltransferase is found in HIV-1 virions and may be important for dimerization and activation of the viral protease [34], (reviewed in [12]); staufen1, an RNA-binding protein is packaged into virions and is involved in incorporation of HIV-1 RNA [8]. Interaction of staufen 1 with $\operatorname{Pr} 55^{\mathrm{Gag}}$ zing finger motifs may also be important for Gag multimerization and formation of the viral capsids [35]. (2) Proteins which have an effect on cDNA synthesis/accumulation: lysyl-tRNA synthetase is incorporated through the interaction with
Gag and is critical for the priming of reverse transcription [36]; uracil DNA glycosylase 2 (UNG2), a cellular DNA repair enzyme that binds HIV-1 integrase and $\mathrm{Vpr}$ $[37,38]$. The role of this enzyme in early post-entry steps of infection remains controversial. The hypothesis that the catalytic activity of Vpr-associated UNG could modulate virus mutation rate and APOBEC3G-mediated G-to-A hypermutations [39-41] was not supported by subsequent studies [42]. However, recently published work of Guenzel and co-authors showed that the virionincorporated nuclear form of UNG2 facilitated reverse transcription through a non-enzymatic mechanism involving direct interaction with the p32 subunit of the replication protein A (RPA) complex [43]. RNA helicase A (RHA or DHX9) is packaged into HIV-1 virions probably through the interaction with an RNA or Gag polyprotein and facilitates reverse transcription [10]. The protein INI1/hSNF5, a member of SWI/SNF chromatin remodeling complex, has been shown to be packaged into virions through the direct binding to integrase [44], and is involved in the synthesis of reverse transcription products [45]. Later studies demonstrated that INI1/ hSNF5 selectively recruits into HIV-1 virions the components of Sin3a-HDAC1 cellular complex, whose presence is critical for the early reverse transcription stage [46]. Furthermore, interaction of HIV-1 integrase with INI1 has been shown to be essential for the nucleosome remodeling of host chromatin and hence overcoming the structural nucleosome barrier for viral integration [47]. (3) Proteins involved in RTC formation, protection and transport: cyclophilin A, which is incorporated into virions via binding to the CA domain of Pr55Gag [23]. The role of CA-bound cyclophilin A in the viral life cycle is still unclear [48] Recently published data showed this protein to be critical for protection and stabilization of HIV-1 cores [49]. It may also be involved in PIC nuclear transport [31]. (4) Restriction factors of the early stages of HIV-1 infection: members of the APOBEC3 family of DNA/RNA editing cytidine deaminases, APOBEC3G (A3G) and APOBEC3F (A3F), are incorporated in Vif-negative virus particles (a small amount of these factors may be present also in Vif-positive virions) and then restrict reverse transcription by carrying out hypermutation of newly synthesized HIV-1 DNA [41,50-52]. Numerous studies have shown that A3G molecules from the target cell have no effect on cDNA deamination, and only virion-incorporated A3G affects viral DNA (reviewed in [53]), suggesting that the cDNA synthesis and accumulation machineries are effectively isolated from the environment of the target cell cytoplasm, but can be affected by factors which are encapsulated in cores and found within RTCs. Initiation of uncoating or disintegration of the capsid shell is believed to be dependent on the completion of reverse transcription 
$[27,28]$. Uncoated complexes containing viral cDNA are capable of interacting with numerous factors of the target cell, which are necessary for nuclear import and probably facilitation of viral genome integration (reviewed [21,54]).

Although numerous studies, including recently published proteomic analyses of whole highly-purified retroviral virions or virus-like particles, contain broad information about profiles of cellular proteins in viral particles $[4,10,55,56]$, the host proteins associated specifically with the cores of mature HIV-1 virions have not been characterized. To identify the proteomic profiles of HIV-1 cores, we performed LC-MS/MS analysis of the cores isolated from virus particles of HIV-1 NL4-3 produced by Sup-T1 cells (T lymphocytes), PMA and vitamin $\mathrm{D}_{3}$ activated THP1 (model of monocyte-derived macrophages), and non-activated THP1 cells (model of monocytes), and Western blot analysis of selected proteins in the cores and producer cells. Potential involvement of identified proteins in the early stages of HIV-1 infection was assessed using gene ontology information and data from published genome-wide screens on proteins important for HIV-1 replication [57-59]. Our study revealed 202 proteins associated with $\mathrm{HIV}-1$ cores. More than $20 \%$ of these proteins were detected in the cores of virions from all cell types, suggesting that this group contains cellular proteins potentially involved in viral replication. We found that some members of this group, which belong to subfamilies of RNA and DNA helicases, are packaged into the virions from producing $\mathrm{T}$ cells more efficiently than into virions from monocyte or MDM model cells, indicating that the mechanism of their incorporation is nonrandom.

\section{Results}

\section{Preparation of HIV-1 core structures for proteomic analysis}

Since HIV-1 is a highly variable virus, its different subtypes and individual variations may interact differently with cellular proteins [60]. Therefore, we selected the NL4-3 isolate of HIV-1 subtype B as a model virus for infection of different cell types: $T$ lymphocytes and the model of monocytes and MDM. NL4-3 is a CXCR4tropic isolate of HIV-1 that normally does not infect monocytes and macrophages, so to infect THP1 cells we used virus pseudotyped with amphotropic murine leukemia virus (MLV) Env glycoprotein. For isolation of viral cores and subsequent LC-MS/MS analysis, we used the virus particles produced by infected Sup-T1 cells (T lymphocyte cell line), THP1 (monocytic leukemia cells) and THP1 cells treated with phorbol 12-myristate 13acetate (PMA) and vitamin $\mathrm{D}_{3}$. This treatment activates cell differentiation that results in acquisition of the biochemical and morphological characteristics of MDM.
Thus, the activated THP1 cells may be considered as a model of macrophages $[61,62]$.

To isolate core structures from HIV-1 virions produced by infected cells, we engaged a technique of "spin-thru" equilibrium density gradient sedimentation described earlier [63-66]. This method of ultra-speed centrifugation of previously concentrated HIV-1 virions through a sucrose density gradient overlaid with a detergent layer (1\% Triton X-100) allows for the purification of mature lentiviral cores whose density varies from 1.23 to $1.27 \mathrm{~g} / \mathrm{ml}[67,68]$ (Figure 1A, lower panel), whereas intact viral particles display buoyant density 1.18$1.20 \mathrm{mg} / \mathrm{ml}$ (Figure 1A, upper panel). To establish the purity of our viral core preparations from cellular vesicles, which have density similar to that of virions (1.14$1.20 \mathrm{~g} / \mathrm{ml}$ ) and may contaminate virus preparations [69], and to compare maturation of capsid cores in the viruses produced by $\mathrm{T}$ lymphocytes and MDM model cells, we engaged electron microscopy and Western blot analysis. Examination of the negatively stained concentrated virion samples in a transmission electron microscope revealed the presence of both extracellular vesicles and viral particles with diameter from 120 to $130 \mathrm{~nm}$ (Figure 1B1-B3). Analysis of ultrathin sections of the viral particles used for core isolation showed that the population represented a mix of immature (Figure 1B4, black double arrows) and mature virions (Figure 1B4, single arrow). The lipid membrane-covered structures were not found in purified viral core preparations. Only the conical-shape and oval structures with length about $80-110 \mathrm{~nm}$ were found in the samples of purified viral cores, indicating that the preparations after "spin-thru" purification contained only mature capsid cores (Figure 1B5-B8). Previous studies of cores from HIV-1 [64] and HIV-2 virions [63] isolated by "spin-thru" centrifugation method showed the presence of mature products of Gag and GagPol proteolytic processing (CA, MA, Vpx [for HIV-2] and RT with high enzymatic activity). Immunoblotting of our core preparations obtained after "spin-thru" purification of the same amounts of Sup-T1- and THP1-derived viral particles, carried out with human IgG prepared from pooled plasma of HIV antibody positive donors, revealed similar amounts of major products of Gag and GagPol processing, such as MA, CA, IN and RT proteins (Figure 1C). The Pr55 $5^{\mathrm{Gag}}$ and $\operatorname{Pr} 41^{\mathrm{Gag}}(\mathrm{MA}+\mathrm{CA})$ have also been identified in the core samples from both viruses, suggesting that mature cores may contain some amounts of unprocessed Gag polyprotein. Taken together, our data indicate that the selected method of purification allows for the isolation of mostly mature cores from the pools of virions produced by both $\mathrm{T}$ lymphocytes and MDM model cells.

We also performed Western blotting of our samples using the anti-CD45 antibody (Figure 2A). CD45 is 


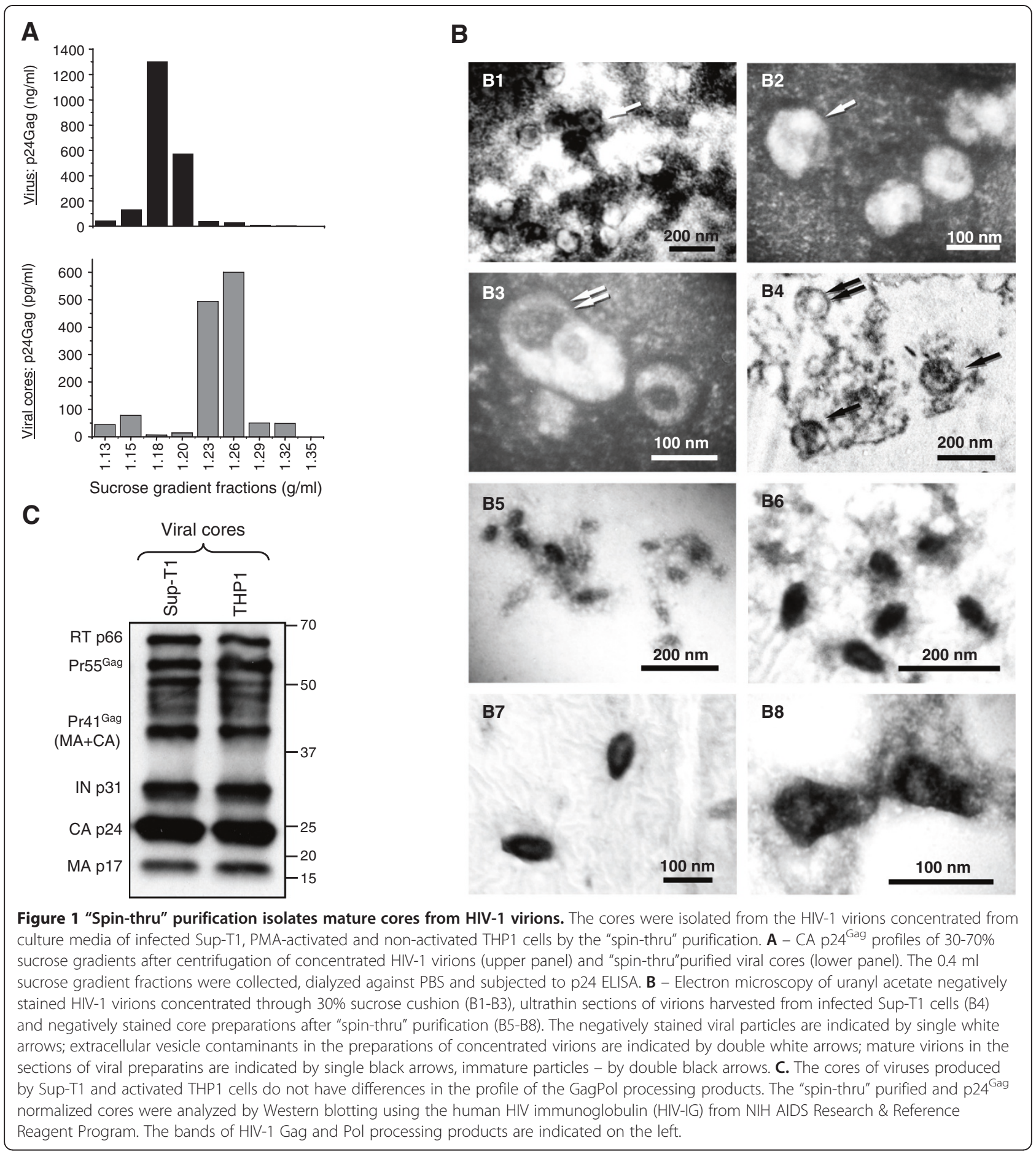

known to be abundant in microvesicles, but is apparently excluded from HIV-1 virions [70]; the lack of this protein in our core preparations would confirm their purity from the vesicular fraction. Indeed, we did not detect CD45 in the samples of cores from HIV-1 virions produced by both Sup-T1 and THP1 cells (Figure 2A, two right lanes), whereas the specimens of culture media from these cells concentrated only through a $30 \%$ sucrose cushion contained detectable amounts of CD45. Western blotting of the samples of culture media from untransfected and NL4-3 proviral clone-transfected 293 T/17 cells using anti-RNA helicase A (RHA or DHX9) antibody showed presence of this DEAD box RNA helicase in the preparations of media from both transfected and untransfected cells after purification through 30\% sucrose. However, in the "spin-thru" 


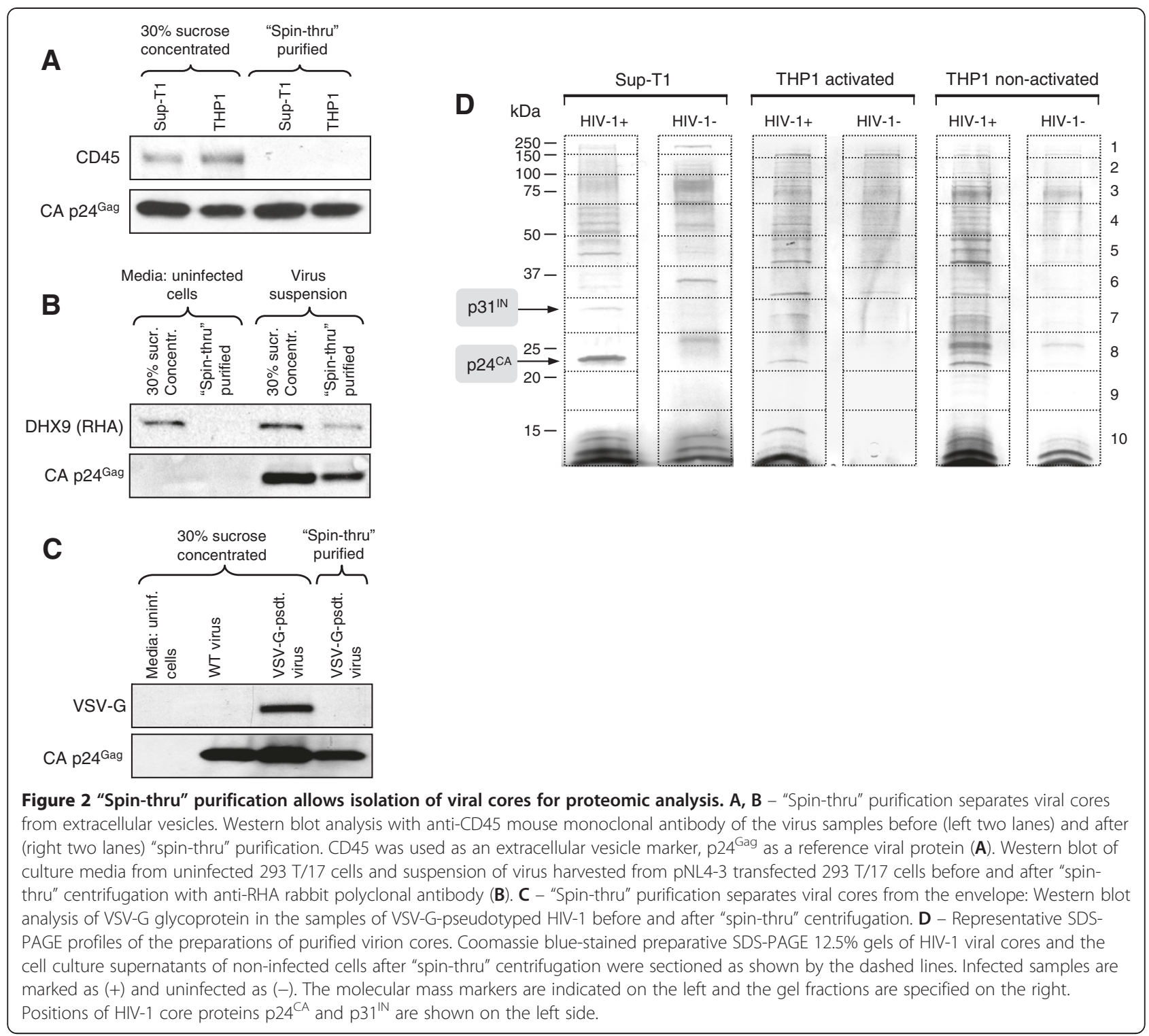

purified samples, RHA was detected only in the preparations of media containing HIV-1 (Figure 2B). Since RHA is known to be present in both vesicles [71] and HIV-1 virions [10,72,73], our analysis confirmed that the method of "spin-thru" centrifugation removed extracellular membranous structures from the 30\% sucroseconcentrated cell culture supernatants, but retained intravirion core structures.

To further prove that "spin-thru" centrifugation purifies cores from intact virions, we tested the presence of VSV-G envelope protein in the samples of VSV-Gpseudotyped HIV-1 produced by co-transfected $293 \mathrm{~T} /$ 17 cells after concentration through $30 \%$ sucrose cushion and "spin-thru" centrifugation (Figure 2C). The VSV-G was clearly detected in the samples of concentrated pseudotyped virus, but was not found in the core samples after "spin-thru" purification, confirming purity of the core preparations from the envelope glycoproteins.

The SDS-PAGE separation of our core preparations (Figure 2D) revealed major bands corresponding to proteins with molecular weights of 24 and $31 \mathrm{kDa}$ (corresponding to HIV-1 CA and IN, respectively), indicating the presence of mature viral Gag and GagPol products in the analyzed core structures. On the other hand, multiple bands corresponding to the polypeptides of different molecular weights, which do not represent known HIV-1 proteins, suggest incorporation of many cellular proteins in the core structures of the viral particles produced by different cell types. The data of proteomic analysis (shown below) confirmed this suggestion. The staining of SDS-PAGE with Coomassie also revealed 
multiple protein bands in the control preparations, suggesting that the culture media from uninfected THP1 and especially Sup-T1 cells contained protein-rich, nonviral, non-membranous particles with buoyant density $\geq 1.23 \mathrm{mg} / \mathrm{ml}$, probably the products of disintegrated dead cells (Figure 2D). Thus, to obtain proteomic profiles of the host proteins associated with HIV-1 viral cores, both viral cores and uninfected control preparations from each cell type were subjected to SDS-PAGE protein separation, trypsin digestion and subsequent LCMS/MS analysis. The protein profile of each viral core sample was then compared with the corresponding control sample. Overlapping proteins were eliminated from the protein spectra of the viral cores, except the proteins whose scores were $>5$-fold higher in the preparations of viral cores than in control samples (proteins such as chaperones Hsp70 and Hsp90, and cytoskeletal proteins $\beta$ actin, $\alpha$ and $\beta$ tubulin, whose presence in core samples was confirmed by Western blot [Figure 4A]). As a result, a total of 202 cellular proteins were found to be associated with the cores of HIV-1 virions.

\section{Proteomic profiling of HIV-1 viral cores}

The proteins obtained from LC-MS/MS analysis of peptide preparations and filtered as described above and in Materials and Methods were categorized according to their functions and subcellular localization using NCBI protein database (http://www.ncbi.nlm.nih.gov/sites/entrez? $\mathrm{db}=$ Protein), NCBI RefSeq database (www.ncbi.nlm.nih. gov/RefSeq/) and DAVID Bioinformatics Resources 6.7 (NIAID NIH) (http://david.abcc.ncifcrf.gov). We compared our data with published results of the genome-wide analyses of cellular proteins involved in HIV-1 infection [57-59,74] and with global network of HIV-human protein-protein interactions [75] to assess the potential role of identified proteins in HIV-1 infection and putative mechanisms of their incorporation into the virion. The HIV-1 proteins identified in the viral cores are summarized in Table 1, the cellular proteins - in Tables 2 and S1 in Additional file 1.

\section{Viral proteins}

The major proteins constituting the HIV-1 nucleocapsid core, CA, NC, IN and RT (both p51 and p66 subunits) were identified in the preparations from virions generated by all cell types (Table 1). All core samples also contained MA protein, which is located in retroviral virions mostly outside the capsid and forms a matrix between the viral capsid and envelope [76,77]. However, presence of MA in the RTCs and PICs [13,14,17,78,79] suggests that this protein is physically associated with the cores of HIV-1 virions. Comparison of our list of identified viral proteins with the MS/MS analysis data of whole MDM-produced HIV-1 particles [4] shows characteristic differences between the protein profiles of viral cores and whole virions. The gp $120^{\text {Env }}$ glycoprotein detected in whole virions is absent in our samples; however, the gp41 transmembrane (TM) Env product was identified in the cores from virions assembled in $\mathrm{T}$ lymphocytes and MDM-like activated THP1 cells. Since gp41 has been found to be associated with MA during virion assembly and probably in mature viral particles $[80,81]$ (reviewed in [82]), a low amount of this glycoprotein in detergent-purified core preparations was expected. The fact that we could not identify gp41 in the cores of virions from non-activated THP1 cells by LCMS/MS confirms our suggestion that the concentration of this glycoprotein in our preparations is negligible. The absence of gp $120^{\text {Env }}$ in our samples confirms purity of isolated core structures from the viral envelope and intact virions, shown also in Figure $2 \mathrm{C}$.

The Tat, Nef and Vif proteins were identified earlier in the viral particles produced by infected MDM using proteomic methods [4]. We did not detect Tat in our core preparations, but MS/MS analysis revealed Nef in the viral cores from all analyzed cell types. Earlier studies indicated that Nef is incorporated into viral particles, stably associates with virion cores and facilitates reverse transcription and early steps of replication $[16,64,83,84]$. The Vif and Rev proteins were identified with low scores only in the cores from $\mathrm{T}$ lymphocyte-derived virus, suggesting their very low concentrations in the cores. HIV1 Vif has been shown to interact with $\operatorname{Pr} 55^{\text {Gag }}$ and viral protease during the assembly of virus particles [85]. Rev protein can be incorporated into cores in the complex with viral RNA. Surprisingly, we did not identify Vpr in the viral core samples. Numerous studies revealed Vpr in HIV-1 virions [86-88] and RTCs [15,89-91]. However, while traditional methods of identification using specific antibodies recognize Vpr in HIV-1 particles, LC-MS/MS analysis performed by Chertova and co-authors [4] also did not reveal this protein in the preparations of whole highly-purified virions. The visibility of protein for LCMS is defined by a few factors, including affinity to $\mathrm{C} 18$ column (hydrophobicity) and ionization efficiency of the peptides. Typically, about $10 \%$ of tryptic peptides of a long protein are visible. Thus, some proteins could be invisible for LC-MS/MS in spite of overall high sensitivity of a method. Moreover, although trypsin cleaves Vpr to 14 peptides, most of them are not charged or have a negative total charge in solution with neutral $\mathrm{pH}$ (analyzed using Innovagen Peptide property calculator tool [http://www.innovagen.se/]), which may cause additional problem with their detection by mass spectrometry.

HIV-1 protease (PR) was observed in all our core preparations. At the same time, detection of Gag and GagPol polyprotein-precursors in respective gel fractions suggests that not all precursor molecules are subjected 
A

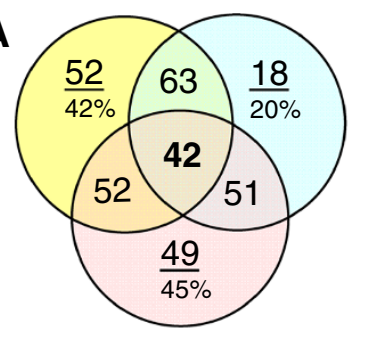

B

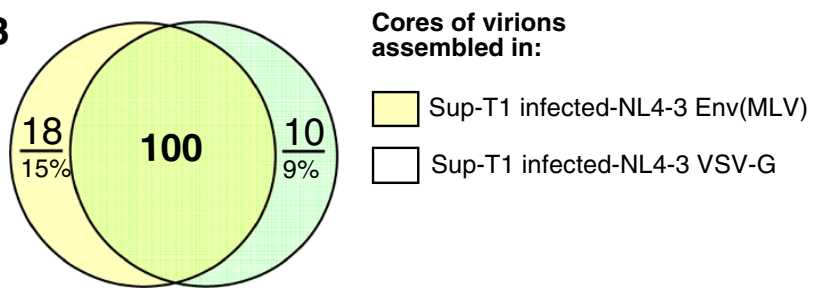

Protein categories (for C1-C4)

DNA binding: chromatin organization, damage repair

RNA binding: organization, modif., splicing, transport

Transcription, transcription regulation

Chaperones

Ubiquitination, proteasome

Cytoskeleton

Regulation of cytoskeleton

Vesicular transport

Nuclear import

Nuclear export

Regulation of cell cycle and differentiation

Signal transduction (incl. apoptosis pathways)

Metabolism, metabolism regulation

Ribosome

Intracellular transport

Nuclear structure, lamina, nucleoli

Extracellular signaling

Translation and translation regulation

Protein post-translation modification

Cell adhesion

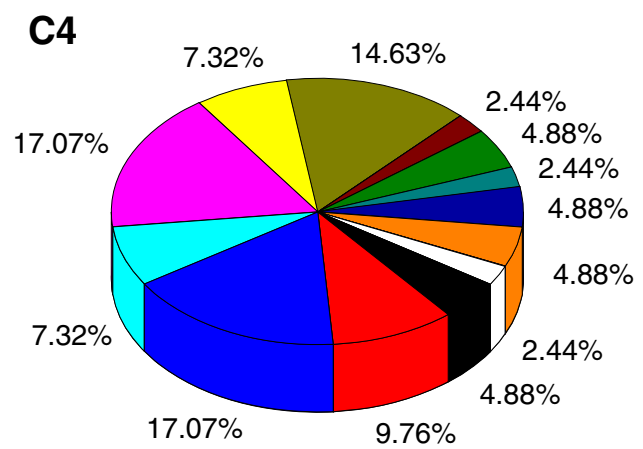

All types

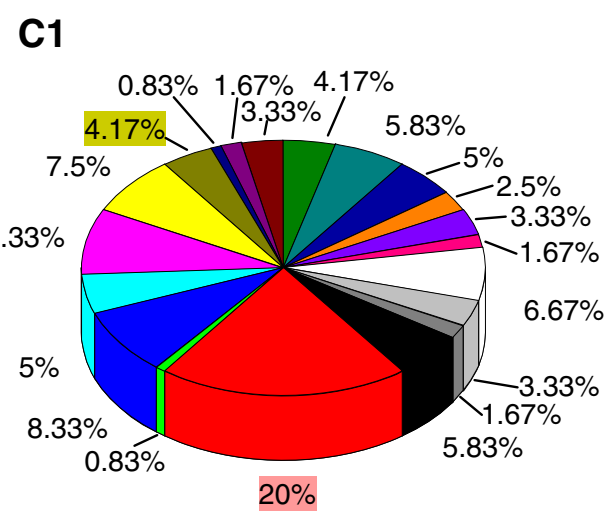

Sup-T1

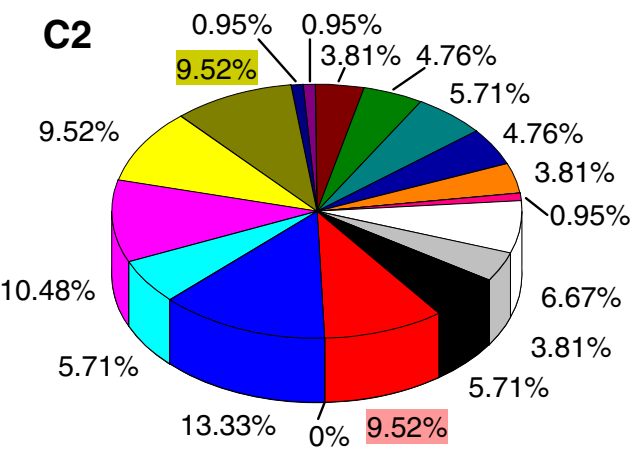

Thp1 activated

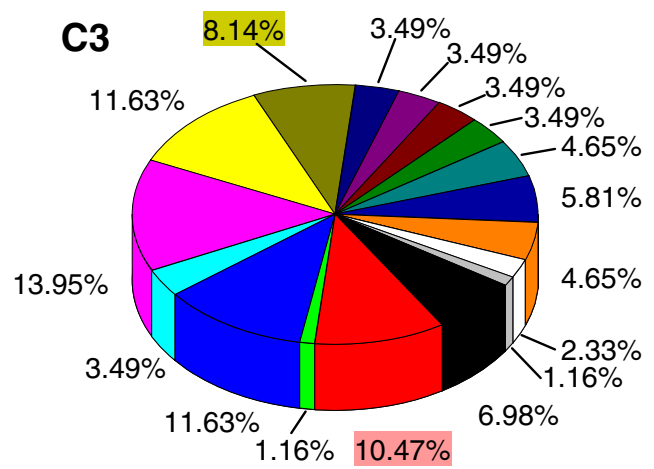

Thp1 non-activated

Figure 3 (See legend on next page.) 
(See figure on previous page.)

Figure 3 Profiles of host proteins associated with the cores of HIV-1 virions from different producer cells - data of LC-MS/MS analysis. A, B - Venn Diagrams depicting the number of overlapping cellular proteins within viral cores among the three producer cell types (A) and within the cores of viruses produced by the same cell type (Sup-T1) infected with HIV-1 NL4-3 strain pseudotyped with MLV Env (yellow) or VSV$G$ (green) envelope glycoproteins (B). The number of non-overlapping proteins and percent of these proteins within all cellular proteins identified in the core are shown as a numerator and denominator respectively. C - Categories of cellular proteins (by function) depicted as a percentage of the total proteins that were identified within the cores of virions produced by Sup-T1 $(\mathbf{C} 1, n=125)$, THP1 cells activated with PMA and vitamin $D_{3}$ ( $\mathbf{C} 2, n=110)$, and non-activated THP1 cells $(\mathbf{C} \mathbf{3}, \mathrm{n}=90)$. The diagram of overlapping cellular proteins detected in all core preparations is shown on C4 $(n=42)$.

to the proteolytic cleavage during the virion assembly and a subset of unprocessed polyproteins is present in the mature viral cores.

\section{Cellular proteins}

Within 202 unique cellular proteins revealed in our preparations of purified cores from HIV-1 virions, the samples from Sup-T1-derived virus included 125 proteins, while the virion cores from activated and non-activated THP1 cells contained 110 and 90 proteins, respectively (Table 2). A similar number of common proteins was found between cores from viruses produced by activated and non-activated THP1 cells (51), non-activated THP1 and Sup-T1 cells (63), and activated THP1 and Sup-T1 (52) (Figure 3A). Forty two proteins were common to all viral cores, which equates to $34 \%, 38 \%$ and $47 \%$ of the proteins found in the cores of viruses derived from Sup-T1, activated and nonactivated THP1 cells, respectively.

We identified 125 host cell proteins in the cores of virions assembled in Sup-T1 cells; cores of the viruses from activated THP1 cells contained $12 \%$ less host proteins, whereas the number of host proteins in the cores of non-activated THP1-derived virus was $28 \%$ less than in the cores of virus from Sup-T1. Interestingly, only $20 \%$ of all cellular proteins identified in the cores of virus from non-activated monocytic cells were unique, other proteins were also found in the cores of the virions derived from Sup-T1 or activated THP1 cells. The cores of activated THP1 and Sup-T1-derived viruses, in contrast, contained $45 \%$ and $42 \%$ of unique host proteins, respectively (Figure 3A). Since the $\mathrm{T}$ lymphocytes and MDM (activated THP1 is a model of MDM) naturally

Table 1 Viral proteins that were detected in viral cores of the virions produced by different types of infected cells ${ }^{a}$

\begin{tabular}{|c|c|c|c|}
\hline \multirow[t]{2}{*}{ Protein } & \multicolumn{3}{|c|}{$\begin{array}{l}\text { Contained in samples } \\
\text { from: }\end{array}$} \\
\hline & $\begin{array}{c}\text { Sup- } \\
\text { T1 }\end{array}$ & $\begin{array}{l}\text { Act. } \\
\text { THP1 }\end{array}$ & $\begin{array}{l}\text { Non-act. } \\
\text { THP1 }\end{array}$ \\
\hline Pr $160^{\text {GagPol }}$ polyprotein-precursor (MA, CA, NC, p6, PR, RT, IN domains) & $\checkmark$ & $\checkmark$ & $\checkmark$ \\
\hline Pol TF (p6*, PR, RT, IN domains) & $\checkmark$ & $\checkmark$ & $\checkmark$ \\
\hline Pol TF (PR, RT domains) & $\checkmark$ & $\checkmark$ & \\
\hline RT p66 subunit & $\checkmark$ & $\checkmark$ & $\checkmark$ \\
\hline $\begin{array}{l}\text { Pr55 Gag polyprotein-precursor ( } M A, C A, s p 2, N C, s p 1, p 6 \text { domains) and probably partially-processed } \mathbf{G a g} \mathbf{4 8} \mathbf{k D a} \\
\text { polyprotein (MA, CA, sp2, NC domains) }\end{array}$ & $\checkmark$ & $\checkmark$ & $\checkmark$ \\
\hline RT p51 subunit & $\checkmark$ & $\checkmark$ & $\checkmark$ \\
\hline gp41 ${ }^{\mathrm{TM}}$ Env glycoprotein & $\checkmark$ & $\checkmark$ & \\
\hline Gag 41 kDa partially-processed polyprotein (MA, CA, sp2 domains) & $\checkmark$ & & \\
\hline IN p31 Pol & $\checkmark$ & $\checkmark$ & $\checkmark$ \\
\hline CA p24 & $\checkmark$ & $\checkmark$ & $\checkmark$ \\
\hline Nef & $\checkmark$ & $\checkmark$ & $\checkmark$ \\
\hline Vif & $\checkmark$ & & \\
\hline MA p17 Gag & $\checkmark$ & $\checkmark$ & $\checkmark$ \\
\hline RNase H 15 kDa Pol polypeptide & $\checkmark$ & $\checkmark$ & $\checkmark$ \\
\hline 15 kDa partially-processed Gag precursor (NC, sp1, p6) & $\checkmark$ & & \\
\hline Rev & $\checkmark$ & & \\
\hline PR p $10^{\text {Pol }}$ & $\checkmark$ & $\checkmark$ & $\checkmark$ \\
\hline $\mathrm{NC} p 7^{\mathrm{Gag}}$ & $\checkmark$ & $\checkmark$ & $\checkmark$ \\
\hline
\end{tabular}

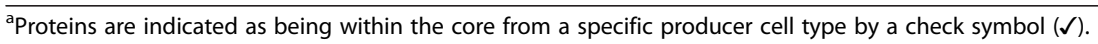
Pol TF, polymerase trans-frame. 
Table 2 Cellular Proteins in HIV-1 cores $^{\mathrm{a}}$

\begin{tabular}{|c|c|c|c|}
\hline Location $^{\mathrm{b}}$ & $\begin{array}{l}\text { Gene } \\
\text { Name }^{c}\end{array}$ & $\begin{array}{l}\text { Accession } \\
\text { Number }^{d}\end{array}$ & Protein Name ${ }^{e}$ \\
\hline & & & DNA Binding: Chromatin Organization, Replication, 7 \\
\hline $\mathrm{N}, \mathrm{C}$ & RUVBL1 & 4506753 & TATA binding protein interacting protein $49 \mathrm{kDa}$ \\
\hline$M, C, N$ & MCM5 & 1232079 & Minichromosome maintenance complex component 5 \\
\hline N & $\mathrm{RCC2}$ & 11360295 & Regulator of chromosome condensation protein 2 \\
\hline $\mathrm{N}, \mathrm{C}$ & RUVBL2 & 5730023 & TBP-interacting protein, 48-KD \\
\hline $\mathrm{N}$ & TOP2B & 288565 & DNA topoisomerase ॥ \\
\hline $\mathrm{N}, \mathrm{C}$ & SSRP1 & 4507241 & Structure specific recognition protein 1 \\
\hline $\mathrm{N}$ & H2AFY & 32492946 & $\mathrm{H} 2 \mathrm{~A}$ histone family, member $\mathrm{Y}$ \\
\hline $\mathrm{N}, \mathrm{C}$ & ERVK-6 & 3600071 & Reverse transcriptase encoded by human endogenous HERV \\
\hline $\mathrm{N}, \mathrm{C}$ & MCM7 & 2134885 & Replication licensing factor MCM7 \\
\hline $\mathrm{N}, \mathrm{M}$ & TEP1 & 1848277 & telomerase-associated protein 1; TP-1 \\
\hline $\mathrm{N}$ & HIST1H1B & 4885381 & $\mathrm{H} 1$ histone family, member $5 ; \mathrm{H} 1 \mathrm{~b}$ \\
\hline $\mathrm{N}$ & HIST1H1C & 4885375 & $\mathrm{H} 1$ histone family, member $2 ; \mathrm{H} 1 \mathrm{~d}$ \\
\hline \multicolumn{4}{|c|}{ Number of Proteins per Cell Type: } \\
\hline & & & DNA Damage Repair \\
\hline $\mathbf{N}$ & XRCC5 & 35038 & Nuclear factor IV - KU80, ATP-dependant DNA helicase II \\
\hline $\mathrm{N}$ & PRKDC & 1362789 & DNA-activated protein kinase \\
\hline N & DDB1 & 12643730 & DNA damage binding protein 1 \\
\hline
\end{tabular}

Number of Proteins per Cell Type:

DNA Binding: Transcription Regulation

N POLR2B 23270691 Polymerase (RNA) II (DNA directed) polypeptide B

N RHOX11 27715523 Similar to Paired-like homeobox protein OTEX

Number of Proteins per Cell Type:

RNA Binding: Structure Organization, Modification, Transport, Splicing

N UPF1 1575536 Regulator of nonsense transcript stability

N DHX9 3915658 ATP-dependent RNA helicase A - DEAD box protein 9

N EFTUD2 24474791 Small nuclear ribonucleoprotein component

N SNRNP20014043179 Helicase hBrr2 200 kDa

N HNRNPM 14141154 Heterogeneous nuclear ribonucleoprotein M isoform b

N,C EIF3A 32449796 Eukaryotic translation initiation factor 3, subunit A

N,C PABPC1 29743688 Poly(A) binding protein, cytoplasmic 1

N PRPF8 17999537 U5 snRNP-specific protein

N,C HNRNPH1 5031753 Heterogeneous nuclear ribonucleoprotein H1

N $\quad$ PDCD7 4416183 ES18 - U12-type spliceosome component

N,C FLII 2135121 Flightless-I homolog

C DDX3X 13514813 Helicase like protein 2 - DEAD/H box polypeptide 3

N,C,Mit DDX17 5453840 RNA-dependent helicase P72 - DEAD box polypeptide 17 isoform 1

N RENT1 1575536 Rregulator of nonsense transcript stability

N,C SYNCRIP 26454828 Synaptotagmin-binding, cytoplasmic RNA-interacting protein

N,C PABP2 12229876 Polyadenylate-binding protein 2

N,C HNRNPR 13629286 Heterogeneous nuclear ribonucleoprotein R

$\mathrm{N}$ SNRNP200 14043179 Small nuclear ribonucleoprotein 200 kDa (U5)

Contained in cores

produced by:

SupT1 Act. N-Act. THP1 THP1
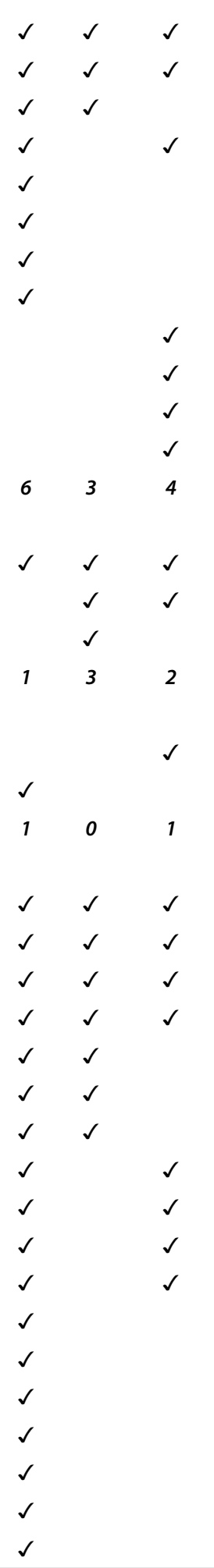
Table 2 Cellular Proteins in HIV-1 cores $^{\text {a }}$ (Continued)

\begin{tabular}{|c|c|c|c|c|c|c|}
\hline C & ACO1 & 9802308 & Iron regulatory protein 1 & $\checkmark$ & & \\
\hline$C, M$ & FHL1 & 6942193 & Four and a half LIM domains 1 protein isoform C & $\checkmark$ & & \\
\hline N & PCBP1 & 444021 & Poly $(\mathrm{rC})$ binding protein 1 & $\checkmark$ & & \\
\hline $\mathrm{N}, \mathrm{C}$ & HNRNPF & 16876910 & Heterogeneous nuclear ribonucleoprotein F & $\checkmark$ & & \\
\hline $\mathrm{N}, \mathrm{C}$ & SRSF3 & 4506901 & Splicing factor, arginine/serine-rich 3 & $\checkmark$ & & \\
\hline N & RALY & 27689091 & Autoantigenic RNA binding protein & & $\checkmark$ & \\
\hline $\mathrm{N}$ & DDX21 & 11890755 & RNA helicase II/Gu protein - DEAD box polypeptide 21 & & $\checkmark$ & \\
\hline N,C,Mit & RTCD1 & 4506589 & RNA 3'-terminal phosphate cyclase & & $\checkmark$ & \\
\hline $\mathrm{N}, \mathrm{C}$ & HNRNPA1 & 30157273 & Heterogeneous nuclear ribonucleoprotein A1 & & $\checkmark$ & \\
\hline $\mathrm{V}, \mathrm{N}, \mathrm{C}$ & $\mathrm{EIF5A2}$ & 9966867 & Eukaryotic translation initiation factor $5 \mathrm{~A} 2$; elF-5A2 protein & & $\checkmark$ & \\
\hline $\mathrm{N}, \mathrm{C}$ & SNUPN & 6730226 & D3b subcomplex of human core snRNP domain & & & $\checkmark$ \\
\hline \multicolumn{4}{|c|}{ Number of Proteins per Cell Type: } & 24 & 11 & 9 \\
\hline \multicolumn{7}{|c|}{ Cytoskeleton } \\
\hline $\mathrm{C}$ & MYH10 & 1346640 & Cellular myosin type $B$, heavy chain & $\checkmark$ & $\checkmark$ & $\checkmark$ \\
\hline $\mathrm{C}$ & MYH9 & 29436380 & Cellular myosin, heavy polypeptide 9 & $\checkmark$ & $\checkmark$ & $\checkmark$ \\
\hline C & TUBA1A & 135395 & Tubulin a 1 & $\checkmark$ & $\checkmark$ & $\checkmark$ \\
\hline $\mathrm{C}$ & TUBA1C & 1438930 & Tubulin a 6 & $\checkmark$ & $\checkmark$ & $\checkmark$ \\
\hline C & TUBB & 1280489 & Tubulin $\beta 5$ & $\checkmark$ & $\checkmark$ & $\checkmark$ \\
\hline C & TUBB3 & 1204535 & Tubulin $\beta 3$ & $\checkmark$ & $\checkmark$ & $\checkmark$ \\
\hline$C$ & ACTBL2 & 2973662 & $\beta$ Actin & $\checkmark$ & $\checkmark$ & $\checkmark$ \\
\hline C & TUBB4 & 2748197 & $\beta$ Tubulin 4Q & $\checkmark$ & $\checkmark$ & \\
\hline C & TUBB1 & 13562114 & Tubulin $\beta 1$ & $\checkmark$ & $\checkmark$ & $\checkmark$ \\
\hline C & TEKT1 & 16753231 & Tektin 1 & $\checkmark$ & & \\
\hline C & DYNC1H1 & 30581065 & Dynein Heavy Chain, cytosolic & & $\checkmark$ & $\checkmark$ \\
\hline C & MYO1F & 1924940 & Myosin-IF & & $\checkmark$ & $\checkmark$ \\
\hline $\mathrm{N}, \mathrm{M}$ & MYO1G & 14269502 & Unconventional myosin IG valine form & & $\checkmark$ & \\
\hline$C, M$ & TUBG1 & 31543831 & Tubulin $y 1$ & & & $\checkmark$ \\
\hline C & TPM2 & 6573280 & Tropomyosin $2(\beta)$ & & & $\checkmark$ \\
\hline \multicolumn{4}{|c|}{ Number of Proteins per Cell Type: } & 10 & 11 & 12 \\
\hline \multicolumn{7}{|c|}{ Cytoskeleton Regulation } \\
\hline C & HSPB1 & 662841 & Heat shock protein 27 & $\checkmark$ & $\checkmark$ & $\checkmark$ \\
\hline $\mathrm{M}, \mathrm{N}$ & MSN & 14625824 & Moesin & $\checkmark$ & $\checkmark$ & $\checkmark$ \\
\hline $\mathrm{C}$ & CORO1A & 5902134 & Coronin, actin binding protein, $1 \mathrm{~A}$ & $\checkmark$ & $\checkmark$ & $\checkmark$ \\
\hline$M, C, V$ & CNP & 180687 & 2',3'-cyclic-nucleotide 3'-phosphodiesterase; CNPase & $\checkmark$ & $\checkmark$ & \\
\hline $\mathrm{N}, \mathrm{C}$ & FLII & 2135121 & Flightless-I homolog & $\checkmark$ & & $\checkmark$ \\
\hline$M, C$ & TTLL10 & 27663488 & Tubulin tyrosine ligase-like family, member 10 & $\checkmark$ & & \\
\hline C & ACTR2 & 27500905 & Human ARP2 actin-related protein 2 homolog (yeast) & $\checkmark$ & & \\
\hline $\mathrm{C}, \mathrm{N}$ & 8-SEP & 12654963 & SEPT11 - Septin filament-forming cytoskeletal GTPase family member 11 & $\checkmark$ & & \\
\hline $\mathrm{N}, \mathrm{C}$ & PFN1 & 3891601 & Human platelet profilin chain A & $\checkmark$ & & \\
\hline $\mathrm{C}, \mathrm{N}$ & ACTR3 & 5031573 & Human ARP3 actin-related protein 3 homolog (yeast) & & $\checkmark$ & \\
\hline C & DNAJA1 & 219588 & DnaJ (Hsp40) homolog, subfamily A, member 1 & & $\checkmark$ & \\
\hline \multirow[t]{2}{*}{ C } & $\mathrm{RHOA}$ & 12654251 & RAS homolog gene family, member A & & $\checkmark$ & \\
\hline & $\begin{array}{l}\text { ARPC4- } \\
\text { TTLL3 }\end{array}$ & 10436409 & $\begin{array}{l}\text { Actin related protein } 2 / 3 \text { complex, subunit } 4 \text {-tubulin tyrosine ligase-like family, member } 3 \\
\text { read-through fusion protein }\end{array}$ & & $\checkmark$ & \\
\hline C & ARPC4 & 15214920 & Actin related protein $2 / 3$ complex, subunit 4 & & $\checkmark$ & \\
\hline
\end{tabular}


Table 2 Cellular Proteins in HIV-1 cores $^{\mathbf{a}}$ (Continued)

\begin{tabular}{llll}
\hline C & RAC2 & 4506381 & RAS-related C3 botulinum toxin substrate 2 \\
M,V,C & TLN1 & 6739602 & Talin \\
M,C & FLNA & 1203969 & Filamin \\
M & SPG8 & 20070788 & Strumpellin \\
C & NCKAP1L & 32425702 & HEM1 protein \\
C & TBCD & 13111855 & Tubulin folding cofactor D \\
M,C & CAP1 & 29739285 & Human adenylyl cyclase-associated CAP protein homolog 1 (S. cerevisiae, S. pombe) \\
Number of Proteins per Cell Type: & \\
& & & \\
N,C & GNB2L1 & $\mathbf{5 1 7 4 4 4 7}$ & Guanine nucleotide binding protein (G protein), beta polypeptide 2-like 1 \\
& MYADM & 27730943 & Myeloid-associated differentiation marker \\
C,V & PTPRC & 10999057 & Protein tyrosine phosphatase \\
M & SEMA7A & 3551779 & Semaphorin L \\
M,C & PKN1 & 1085381 & Serine/threonine protein kinase \\
C,M & MMP14 & 1705985 & Matrix metalloproteinase 14 \\
C & TIMP3 & 1304484 & Tissue inhibitor of metalloproteinases-3 \\
Number of Proteins per Cell Type:
\end{tabular}

Number of Proteins per Cell Type:

\section{Nuclear Import}

N,C TNPO1 27681051 Karyopherin $\beta 2$; importin $\beta$ 2; transportin; transportin 1

V,N TNPO3 6912734 Transportin-SR; importin 12; transportin-SR2

N,C KPNB1 19923142 Karyopherin $\beta 1$; importin 90; importin $\beta-1$

N $\quad$ KPNA2 1354365 Karyopherin a2; RAG cohort 1, importin a1

Number of Proteins per Cell Type:

\section{Nuclear Export}

$\begin{array}{llll}\text { N } & \text { XPO5 } & 12407633 & \text { RANBP21/exportin } 5 \\ \text { N,C } & \text { XPOT } & 17367977 & \text { Exportin T (tRNA exportin) }\end{array}$

Number of Proteins per Cell Type:

\section{Apoptosis}

\section{HP95 13375569 Programmed cell death 6 interacting protein}

Number of Proteins per Cell Type:

\section{Extracellular Signaling}

V,C,M PTPRC 10999057 Protein tyrosine phosphatase, receptor type, C

C AIMP1 27065983 Aminoacyl tRNA synthetase complex-interacting multifunctional protein 1

M CLEC1A 30159086 C-type lectin domain family 1, member A

Number of Proteins per Cell Type:

Intracellular Transport

$\begin{array}{llll}\text { C,M } & \text { CLTC } & \mathbf{3 0 3 5 3 9 2 5} \text { Clathrin, heavy chain (Hc) } \\ \text { M,C } & \text { RAB8A } & \mathbf{2 3 4 7 4 6} & \text { RAB8A, member RAS oncogene family } \\ \text { M } & \text { CPNE1 } & 4503013 & \text { Copine I } \\ \text { C,N } & \text { TNIP1 } & 1800305 & \text { TNFAIP3 interacting protein 1; HIV-1 Nef interacting protein } \\ \text { M,N,C } & \text { GC } & 18655422 & \text { Vitamin D binding protein } \\ \text { M,C } & \text { AP2B1 } & 33504652 & \text { Adaptor-related protein complex 2, } \beta 1 \text { subunit }\end{array}$


Table 2 Cellular Proteins in HIV-1 cores $^{\mathbf{a}}$ (Continued)

RNA Stability Regulation

C,N RNH1 15029922 Ribonuclease/angiogenin inhibitor 1

Number of Proteins per Cell Type:

Nuclear Lamina, intranuclear components

N $\quad$ LMNB1 15126742 lamin B1

N $\quad$ NCL 21750187 Nucleolin

N DKC1 14602859 Dyskerin; dyskeratosis congenita 1

N $\quad$ RPL3 18606060 Ribosomal protein L3

Number of Proteins per Cell Type:

Cell adhesion

M,C PCDHGA7 14196477 Protocadherin gamma subfamily A, 7

M HABP2 4758502 Hyaluronan binding protein 2

Number of Proteins per Cell Type:

\section{Mitochondria}

Mit SLC25A6 113463 Solute carrier family 25 (mitochondrial carrier; adenine nucleotide translocator), member 6 Number of Proteins per Cell Type:

\section{Lipid Biosynthesis}

C,N FDFT1 11514495 Farnesyl-diphosphate farnesyltransferase 1

M,C FASN 15779138 Fatty acid synthase

Number of Proteins per Cell Type:

\section{Transmembrane lon Transport}

N,M SLC4A10 7513341 Sodium bicarbonate cotransport protein 2

C,M ATP6VOE2 542837 ATPase, $\mathrm{H}+$ transporting V0 subunit e2

Number of Proteins per Cell Type:

Cell-Cell Transport

M,C ESYT1 7512911 Extended synaptotagmin-like protein 1

Number of Proteins per Cell Type:

Ribosomal

$\begin{array}{llll}\mathbf{R} & \text { RPL7A } & \mathbf{4 5 0 6 6 6 1} & \mathbf{6 0} \text { S-L7A } \\ \mathbf{R} & \text { RPL18A } & \mathbf{1 1 4 1 5 0 2 6} 60 \text { S-L18A } \\ \text { R } & \text { RPL7A } & 17456110 & 60 \text { S-L7 } \\ \text { R } & & 27483402 & 40 \text { S-S2 } \\ R & \text { RPL7L1 } & 27498574 & 60 \text { S-L7Like1 } \\ R & \text { RPL13 } & 15431295 & 60 \text { S-L13 } \\ R & \text { RPL24 } & 4506619 & 60 \text { S-L24 } \\ R & \text { RPS8 } & 4506743 & 40 \text { S-S8 }\end{array}$

Number of Proteins per Cell Type:

\section{Ubiquitin/Proteasome}

C,N UBA1 $24485 \quad$ Ubiquitin-like modifier activating enzyme 1

C BFAR 27675450 Bifunctional apoptosis regulator

N,C PSMC3 107855 Proteasome (prosome, macropain) 26 S subunit, ATPase, 3

C PSMD7 2134660 Proteasome (prosome, macropain) $26 \mathrm{~S}$ subunit, non-ATPase, 7

M,C PSMB1 12653473 Proteasome (prosome, macropain) subunit, $\beta$ type, 1

N,C PSMD11 2150046 Proteasome (prosome, macropain) $26 \mathrm{~S}$ subunit, non-ATPase, 11

C,N PAAF1 33150632 Proteasomal ATPase-associated factor 1 
Table 2 Cellular Proteins in HIV-1 cores $^{\text {a }}$ (Continued)

\begin{tabular}{llll}
\hline C,N & RPN1 & 14124942 & Ribophorin I \\
N,C & PSMD3 & 16550621 & Proteasome (prosome, macropain) 26 S subunit, non-ATPase, 3 \\
Number of Proteins per Cell Type: & & \multicolumn{1}{c}{ Metabolism, Metabolism Regulation } \\
M & PFKP & $\mathbf{1 1 3 2 1 6 0 1}$ Phosphofructokinase, platelet \\
C,N,M & ACLY & 13623199 & ATP citrate lyase \\
M,C & PYGL & 10120741 & Chain A, Human Liver Glycogen Phosphorylase A \\
N,C & GPT & 1507680 & Glutamic-pyruvate transaminase (alanine aminotransferase) \\
C,M & PKM2 & 125604 & Pyruvate kinase, M2 isozyme \\
C & SLC2A1 & 3387905 & Solute carrier family 2 (facilitated glucose transporter), member 1 \\
N,C & TPI1 & 16877874 & Triosephosphate isomerase 1
\end{tabular}

Number of Proteins per Cell Type:

\section{Cell Cycle Regulation/Cell Differentiation}

$\begin{array}{llll}\text { N } & \text { CCNB3 } & \mathbf{1 4 7 1 9 4 2 0} \text { Cyclin B3 isoform 3 } \\ \text { C } & \text { PPP2R1A } & 21749746 & \text { Protein phosphatase 2A, regulatory subunit A, a } \\ \text { C,M } & \text { RAP1B } & 12751117 & \text { RAP1B, member of RAS oncogene family } \\ \text { C,N } & \text { PPP2R3B } & 7019501 & \text { Protein phosphatase 2A, regulatory subunit B", B; PP2A B" } \\ \text { N,C } & \text { CDK11A } & 16357490 & \text { Cyclin-dependent kinase 11A } \\ \text { C } & \text { PRDX3 } & 32483377 & \text { Peroxiredoxin 3 isoform b } \\ \text { C } & \text { TIMP3 } & 1304484 & \text { TIMP metallopeptidase inhibitor 3 }\end{array}$

Number of Proteins per Cell Type:

\section{Nucleotide Biosynthesis}

C CAD 18105007 Carbamoyl-phosphate synthetase 2, aspartate transcarbamylase, and dihydroorotase Number of Proteins per Cell Type:

\section{Amino Acid Biosynthesis}

M,C,N PHGDH $5771521 \quad$ 3-phosphoglycerate dehydrogenase

C ASS1 16950633 Argininosuccinate synthase 1

C GCN1L1 2282576 HsGCN1; GCN1 general control of amino-acid synthesis 1-like 1 (human homolog of yeast) Number of Proteins per Cell Type:

\section{Vesicular Transport}

$\begin{array}{llll}\text { C,M } & \text { CLTC } & 30353925 & \text { Clathrin } \\ \text { C,M,V } & \text { COPA } & \mathbf{4 7 5 8 0 3 0} & \text { Coatomer protein complex, subunit a; alpha coat protein; xenin } \\ \text { V,C } & \text { MVP } & 19913410 & \text { Major Vault Protein } \\ \text { C,V } & \text { TFRC } & \mathbf{4 5 0 7 4 5 7} & \text { Transferrin receptor (p90, CD71) } \\ \text { C,V } & \text { RAB7A } & \mathbf{1 7 0 9 9 9 9} & \text { RAB7A, member RAS oncogene family } \\ \text { C } & \text { PDCD6IP } & \mathbf{1 3 3 7 5 5 6 9} & \text { Programmed cell death } 6 \text { interacting protein, HP95, AIP1/ALIX } \\ \text { C } & \text { RAB5C } & 4759020 & \text { RAB5C, member RAS oncogene family } \\ \text { C,V } & \text { EHD4 } & 7212811 & \text { EH-domain containing 4 } \\ \text { C } & \text { SAR1A } & 21634445 & \text { GTP-binding protein Sara; SAR1 homolog A (S. cerevisiae) } \\ \text { M,V } & \text { ARFRP1 } & 1065361 & \text { Chain A, Human Adp-ribosylation factor related protein 1 } \\ \text { V,N } & \text { ATP6V0A1 } 1638835 & \text { ATPase, H + transporting, lysosomal V0 subunit a1 } \\ \text { C } & \text { RAB11A } & 4758984 & \text { RAB11A, member RAS oncogene family }\end{array}$


Table 2 Cellular Proteins in HIV-1 cores $^{\mathbf{a}}$ (Continued)

\begin{tabular}{|c|c|c|c|c|c|c|}
\hline \multicolumn{7}{|c|}{ Aminoacyl tRNA synthetases } \\
\hline $\mathrm{C}, \mathrm{N}$ & IARS & \multicolumn{2}{|c|}{31873336 Isoleucyl-tRNA synthetase } & $\checkmark$ & $\checkmark$ & $\checkmark$ \\
\hline $\mathrm{C}, \mathrm{N}$ & MARS & 15929104 & Methionyl-tRNA synthetase & $\checkmark$ & & $\checkmark$ \\
\hline $\mathrm{C}, \mathrm{N}$ & RARS & 2118344 & Arginyl-tRNA synthetase & $\checkmark$ & & \\
\hline $\mathrm{C}, \mathrm{N}$ & GARS & 3845409 & Glycyl-tRNA synthetase & $\checkmark$ & & \\
\hline C,Mit & WARS & 8439415 & Tryptophanyl-tRNA synthetase & $\checkmark$ & & \\
\hline $\mathrm{C}, \mathrm{N}$ & DARS & 4557513 & Aspartyl-tRNA synthetase & & $\checkmark$ & \\
\hline $\mathrm{C}, \mathrm{N}$ & QARS & 11493441 & Glutaminyl-tRNA synthetase & & $\checkmark$ & \\
\hline \multicolumn{4}{|c|}{ Number of Proteins per Cell Type: } & 5 & 3 & 2 \\
\hline \multicolumn{7}{|c|}{ Translation and Translation Regulation } \\
\hline $\mathrm{N}, \mathrm{C}$ & EIF3A & 32449796 & Eukaryotic translation initiation factor 3 , subunit A & $\checkmark$ & $\checkmark$ & \\
\hline C & $\mathrm{EEF} 2$ & 4503483 & Eukaryotic translation elongation factor 2; polypeptidyl-tRNA translocase & $\checkmark$ & & \\
\hline C & CC2D1B & 27715655 & Coiled-coil and C2 domain containing 1B & $\checkmark$ & & \\
\hline C & CYFIP1 & 24307969 & Cytoplasmic FMR1 interacting protein 1 (Sra1) & & $\checkmark$ & \\
\hline C & AIMP2 & 27662300 & Aminoacyl tRNA synthetase complex-interacting multifunctional protein 2 & & $\checkmark$ & \\
\hline $\mathrm{V}, \mathrm{N}, \mathrm{C}$ & EIF5A2 & 9966867 & Eukaryotic translation initiation factor $5 \mathrm{~A} 2$; elF-5A2 protein & & $\checkmark$ & \\
\hline Number & of Proteins $p$ & er Cell Type: & & 3 & 4 & 0 \\
\hline \multicolumn{7}{|c|}{ Protein Post-Translation Modification } \\
\hline$C, M$ & PAFAH1B & 4505587 & Platelet-activating factor acetylhydrolase 1b, catalytic subunit 3 & $\checkmark$ & & \\
\hline $\mathrm{N}, \mathrm{C}$ & PARP1 & 130781 & Poly [ADP-ribose] polymerase-1 & $\checkmark$ & & \\
\hline C & USP14 & 4827050 & Ubiquitin specific protease 14 & $\checkmark$ & & \\
\hline $\mathrm{C}, \mathrm{N}$ & SERPINC1 & 4502261 & Serpin peptidase inhibitor, clade C (antithrombin), member 1 & $\checkmark$ & & \\
\hline$M, C$ & LPL & 15030193 & Lipoprotein lipase & & $\checkmark$ & \\
\hline$M, C$ & NMT1 & 345862 & N-myristoyltransferase 1 & & $\checkmark$ & \\
\hline$C, M$ & CPD & 21903712 & Carboxypeptidase D & & $\checkmark$ & \\
\hline Number & of Proteins $p$ & er Cell Type: & & 4 & 3 & 0 \\
\hline \multicolumn{7}{|c|}{ Protein Degradation (non-proteasomal) } \\
\hline M & ANPEP & 28678 & Alanyl (membrane) aminopeptidase & & $\checkmark$ & \\
\hline Number & of Proteins $p$ & er Cell Type: & & 0 & 1 & 1 \\
\hline \multicolumn{7}{|c|}{ Chaperones/Molecular Folding } \\
\hline C & DNAJC13 & 7513063 & DnaJ (Hsp40) homolog, subfamily C, member 13 & $\checkmark$ & $\checkmark$ & $\checkmark$ \\
\hline C & HSP90AB & 120149594 & Heat shock protein $90 \mathrm{kDa}$ a (cytosolic), class B member 1 & $\checkmark$ & $\checkmark$ & $\checkmark$ \\
\hline $\mathrm{C}, \mathrm{N}$ & HSPA8 & 24234686 & 5 Heat shock $70 \mathrm{kDa}$ protein 8 & $\checkmark$ & $\checkmark$ & $\checkmark$ \\
\hline$C, M, N$ & ССТ3 & 2136253 & $\begin{array}{l}\text { Chaperonin containing t-complex polypeptide } 1 \text { (TCP1), subunit } 3(\gamma) \text {; TCP1 ring } \\
\text { complex protein TRiC5 }\end{array}$ & $\checkmark$ & $\checkmark$ & $\checkmark$ \\
\hline $\mathrm{C}, \mathrm{M}$ & CCT6A & 4502643 & Chaperonin containing t-complex polypeptide 1 (TCP1), subunit 6A (乙1) & $\checkmark$ & $\checkmark$ & $\checkmark$ \\
\hline $\mathrm{C}, \mathrm{M}$ & CCT6B & 22654293 & Chaperonin containing t-complex polypeptide 1 (TCP1), subunit $\zeta 2$ & $\checkmark$ & $\checkmark$ & $\checkmark$ \\
\hline C & HSPB1 & 662841 & Heat shock 27 kDa protein 1 & $\checkmark$ & $\checkmark$ & $\checkmark$ \\
\hline C & PPIA & 2624881 & Human Cyclophilin A & $\checkmark$ & $\checkmark$ & $\checkmark$ \\
\hline N & NAP1L4 & 5174613 & Nucleosome assembly protein 1-like 4; nucleosome assembly protein 2 & $\checkmark$ & & $\checkmark$ \\
\hline $\mathrm{N}, \mathrm{M}, \mathrm{C}$ & TCP1 & 13540473 & t-complex polypeptide 1 (TCP1) & $\checkmark$ & & $\checkmark$ \\
\hline $\mathrm{N}, \mathrm{C}$ & CCT5 & 12804225 & Chaperonin containing t-complex polypeptide 1 (TCP1), subunit $5(\epsilon)$ & $\checkmark$ & & \\
\hline C & $\mathrm{P} 4 \mathrm{HB}$ & 20070125 & Prolyl 4-hydroxylase, $\beta$ polypeptide & & $\checkmark$ & \\
\hline C & $\mathrm{CCT7}$ & 5453607 & Chaperonin containing t-complex polypeptide 1 (TCP1), subunit $\eta$ & & $\checkmark$ & \\
\hline C & SERPINH1 & 123576 & Serpin peptidase inhibitor, clade $\mathrm{H}$ (heat shock protein 47), member 1 & & $\checkmark$ & \\
\hline
\end{tabular}


Table 2 Cellular Proteins in HIV-1 cores $^{\text {a }}$ (Continued)

\begin{tabular}{|c|c|c|c|c|c|}
\hline C & HYOU1 & 5453832 & Oxygen regulated protein 1 & $\checkmark$ & \\
\hline C & CANX & 10716563 & Calnexin & $\checkmark$ & \\
\hline Mit & HSPA9 & 12653415 & Heat shock 70 kDa protein 9 (mortalin) & $\checkmark$ & \\
\hline C,N & $\mathrm{CCT} 4$ & 2559008 & Chaperonin containing t-complex polypeptide 1 (TCP1), subunit $\delta$ & & $\checkmark$ \\
\hline \multicolumn{3}{|c|}{ Number of Proteins per Cell Type: } & 10 & 13 & 10 \\
\hline
\end{tabular}

support productive HIV-1 infection, whereas the nondifferentiated monocytes may serve as HIV-1 reservoirs, but do not support active replication (reviewed in [92]), the incorporation of a smaller number of cellular proteins by the virions released from non-activated THP1 is probably related to the lower efficiency of virion assembly in this type of cells.

To validate the credibility of differences in protein composition between viral cores from different cell lines, we performed proteomic analysis of two core preparations purified from the same cell line. Cores of virions harvested from Sup-T1 cells infected with MLV Envpseudotyped and VSV-G-pseudotyped NL4-3 viruses were digested by trypsin without gel separation and subjected to LC-MS/MS. Per one hundred high scoring overlapping proteins we found only 18 unique cellular proteins incorporated in the viral cores from the MLV Env-pseudotyped virus-infected Sup-T1 (15\% of all incorporated host proteins) and 10 proteins (9\%) in cores of the virus from Sup-T1 cells infected with VSVG-pseudotyped NL4-3 strain (Figure 3B; Additional file 1: Table S1). Since the minimal difference in the spectra of host proteins between cores of virions harvested from different cell lines was not less than $20 \%$, and was equal to $42 \%$ and $45 \%$ for the viral cores from Sup-T1 and activated THP1 cells, respectively, relative to cores from non-activated THP1 cells, we believe that the detected differences between the profiles of cellular proteins in the viral cores from various cell lines are significant.

All the cellular proteins in HIV-1 cores were classified into 31 functional categories (Table 2). The most numerous categories were as follows: RNA-binding proteins (29), components of the cytoskeleton (15) and cytoskeleton regulators (21), chaperones (18), DNA-binding proteins (17), proteins involved in vesicular transport (12) and components of the ubiquitin-proteasome system (9). Although these protein groups were numerous in all preparations, the viruses assembled in different types of producer cells demonstrated diversity in the protein spectra and number of proteins within each group (Figure 3C).
Within the forty two cellular proteins which were present in all core preparations, the spectra of molecular chaperones (7), cytoskeleton components (7), and vesicular transport-associated proteins (5) were the most numerous (Figure 3C4). These functional groups of proteins have been shown to be involved in the folding of viral proteins and HIV-1 virion assembly (reviewed in $[12,93])$. Some of these proteins (clathrin, transferrin receptor 1, RAB7, RAB5C, EHD4, Hsp70, Hsp90, cyclophilin $A, \beta$ actin, tubulin $\alpha 1$ ) are very typical for HIV-1 virions and were registered earlier in the samples of purified viral particles (summarized in the database of Host Proteins in HIV-1 [http://web.ncifcrf.gov/research/ avp/protein_db.asp]). Probably some of these proteins, such as $\beta$ actin, $\alpha$ and $\beta$ tubulin, moesin and major vault protein 1 are incorporated into HIV-1 virions non-specifically, due to their close proximity to a budding site, as suggested earlier [4,94], whereas other cellular proteins may be incorporated due to specific interactions with viral proteins, such as Gag and GagPol [11,23,33], viral genomic RNA [8], or tRNA ${ }^{\text {Lys3 }}$ primer [73]. These host proteins, called "Captives" in a recent review [12], may be involved in the virion assembly and budding process or be important for post-assembly steps of HIV1 life cycle. Below we attempt to assess the packaging of selected cellular proteins in the cores of HIV-1 virions depending on the type of producer cells.

\section{Semi-quantitative analysis of selected cellular proteins packaging into the cores of HIV-1 virions assembled in different types of cells}

Although the spectra of the cellular proteins incorporated in the viral cores depended on the type of virusproducing cells, the quantitative differences within the group of overlapping proteins could also be observed. We compared the abundance of certain cellular proteins, selected from the group of 42 common proteins, in the viral cores and lysates of the producer cells. Since the group of 42 cellular proteins identified in all viral cores included the members which are likely involved in viral replication (Table 3), we selected 7 proteins from 


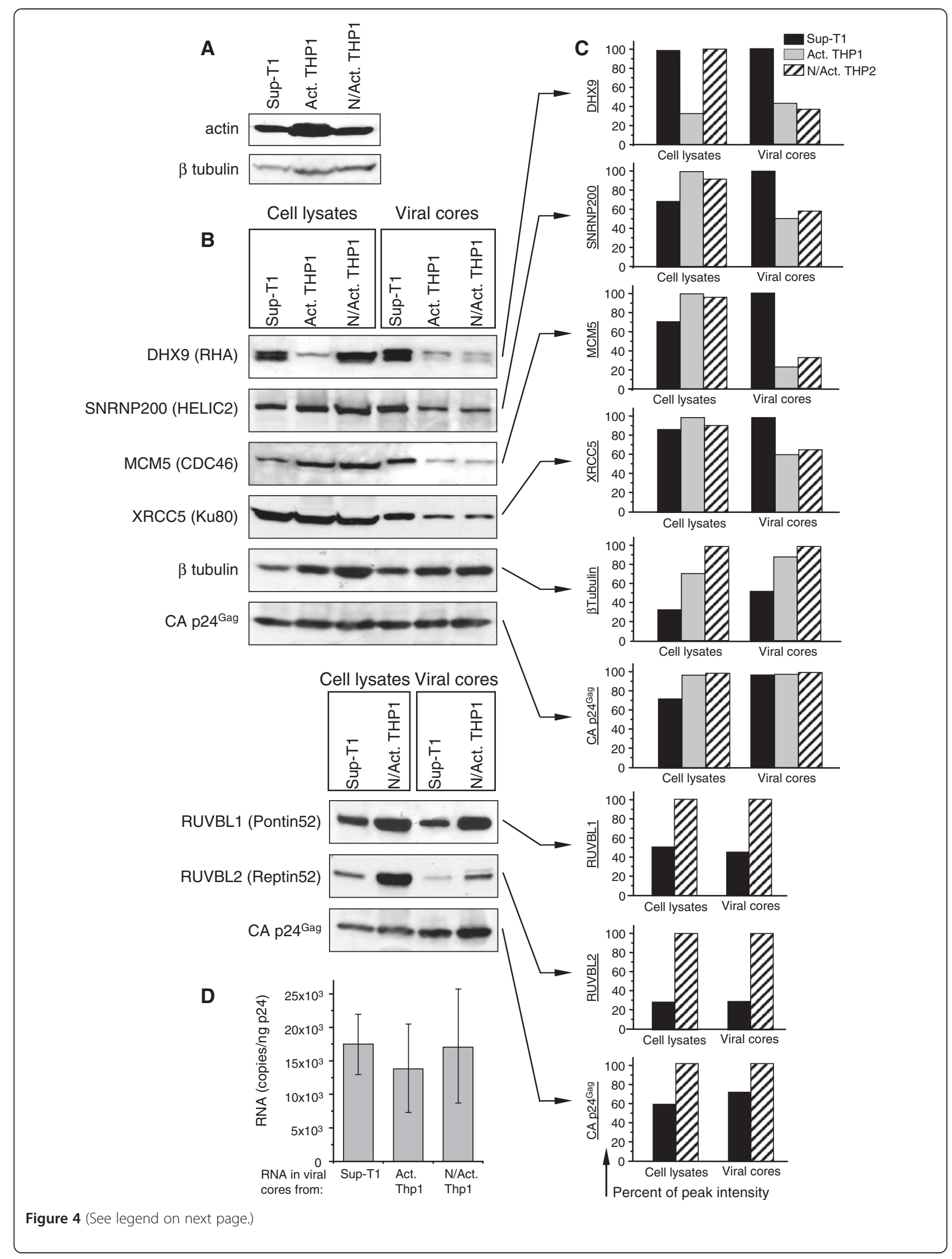


(See figure on previous page.)

Figure 4 Incorporation of certain RNA- and DNA-binding cellular proteins into HIV-1 viral cores does not correlate with abundance of these proteins in infected cells. A - Western blot detection of the cytoskeleton proteins actin and $\beta$ tubulin in uninfected Sup-T1, activated and non-activated THP1 cells. Lysates were normalized according to cell counts and then according to the count of $\beta$ globin DNA using quantitative real-time PCR, and subjected to SDS-PAGE and Western blot analysis. $\mathbf{B}$ - Western blot detection of cellular RNA-binding proteins (DHX9, SNRNP200), DNA- binding proteins (MCM5, XRCC5, RUVBL1, RUVBL2), cytoskeleton protein $\beta$ tubulin, and viral protein CA p24 ${ }^{\text {Gag }}$ in the lysates of virus-producing cells (left bands) and in "spin-thru" purified viral cores (right bands). Virus was harvested at $72 \mathrm{~h}$ p.i. from Sup-T1, activated and non-activated THP1 cells infected with MLV Env-pseudotyped HIV-1 NL4-3, normalized to CA p24"Gag and subjected to the "spinthru" core isolation. Lysates of infected cells were normalized according to total protein count and $\beta$ globin DNA count as described in A. Cellular and viral core preparations were analyzed by Western blotting. C - Quantification of Western blotting results. Western blotting data were quantified using ImageJ software. Results are presented as percentage of the peak value for each protein in the cellular and viral core preparations. D - Quantification of viral genomic RNA in the cores of virions. Viral cores were prepared as described in Figure 1. RNA was isolated from CA p24 ${ }^{\text {Gag }}$-normalized core samples, subjected to reverse transcription with oligo-dT primer and then to quantitative real-time PCR with the primer set specific for positive-strand HIV-1 DNA. The data represents analysis of three independent preparations. Each point shows mean RNA copy number \pm SD per $1 \mathrm{ng}$ of $\mathrm{p} 24^{\mathrm{CA}}$ in the viral core sample.

different functional categories for analysis by Western blot. Within the group of RNA-binding proteins, we analyzed incorporation of RNA helicase A, because the function of this protein in HIV-1 replication has been shown earlier [10,95], and small nuclear ribonucleoprotein $200 \mathrm{kDa}$ (U5) (SNRNP200 or HELIC2), which currently has no known role in HIV replication but has been detected with a high score in our MS/MS preparations. Within DNA-binding group of proteins, we analyzed the Minichromosome maintenance complex component 5 (MCM5) involved in initiation of DNA replication, 80-kilodalton subunit of the $\mathrm{Ku}$ heterodimer protein or ATP-dependant DNA helicase II (Ku80 or XRCC5), which is involved in the repair of DNA doublestrand breaks and telomerase function [96,97], Pontin52 (RUVBL1) and Reptin52 (RUVBL2) DNA helicases, both being the components of several high molecular weight protein complexes involved in chromatin remodeling, transcription regulation, DNA damage sensing and repair [98]. All these DNA-binding proteins were detected with high scores by LC-MS/MS in the cores of virions from both Sup-T1 and THP1 cells. Beta tubulin was selected as one of the major cytoskeletal proteins found earlier in HIV-1 particles (http://web.ncifcrf.gov/research/avp/protein_db.asp). All preparations were normalized to CA p $24^{\text {Gag }}$; the cell lysates were additionally normalized by the cell count and $\beta$ globin DNA count using quantitative real-time PCR. Cytoskeletal proteins, such as actin or $\beta$ tubulin, could not be used for normalization of the cell lysates, because they are differently expressed in uninfected Sup-T1 and THP1 cells (Figure 4A).

Analysis of selected proteins using Western blot with subsequent quantification of the band intensity using ImageJ software did not reveal differences in the abundance of $\beta$ tubulin between the infected cells and the cores of virions produced by these cells (Figure 4B,C). The same ratio of protein concentrations between cells and viral cores was also detected for RUVBL1 and
RUVBL2 DNA helicases. However, other analyzed DNAand RNA-binding proteins demonstrated either moderate (XRCC5, SNRNP200) or high prevalence (MCM5, DHX9) in the cores of virions assembled in Sup-T1 cells, whereas in the cores of THP1-derived virions (both activated and non-activated) these proteins were less abundant. Incorporation of these proteins in the viral cores did not correlate with their abundance in the producer cells: XRCC5, MCM5 and SNRNP200 were presented in all types of cells at a similar level, whereas the RNA helicase A (DHX9) was abundant in dividing Sup-T1 and non-activated THP1 cells and decreased in non-dividing activated THP1 (Figure 4B,C). Interestingly, the incorporation of RNA helicases DHX9 and SNRNP200 into the cores did not correlate with the packaging of viral genomic RNA, as quantitative RT-PCR of the RNA isolated from $\mathrm{CA}$ p $24^{\mathrm{Gag}}$-normalized purified viral cores revealed no significant differences in the count of HIV-1 RNA in the cores from Sup-T1 and both THP1-derived viruses (Figure 4D).

\section{Discussion}

The proteomic analysis of the cores isolated from HIV-1 virions assembled in $\mathrm{T}$ lymphocytes and activated (model of MDM) and non-activated monocytic cells revealed more than thirty cellular proteins which have been previously shown to be involved in different steps of $\mathrm{HIV}-1$ replication and/or incorporated in $\mathrm{HIV}-1$ virions (Table 3). Since HIV-1 is a retrovirus with a RNA genome of less than $10 \mathrm{kB}$ and encodes only nine polypeptides, it engages numerous cellular factors and pathways at all stages of its life cycle. Some of the factors, especially proteins involved in RNA splicing and nuclear export, multi-vesicular bodies (MVB) and late endosomal pathway, as well as the proteins directly involved in the HIV-1 budding process, such as AIP1/Alix, may be incorporated into virions by being associated with the viral RNA and proteins, but do not play a visible role in subsequent stages of viral replication [4,125,130]. For 
Table 3 Previously discovered viral proteins with a known role in HIV-1 Replication ${ }^{\text {a }}$

\begin{tabular}{ccc}
\hline Protein $^{b}$ & $\begin{array}{c}\text { Gene } \\
\text { name }^{c}\end{array}$ & $\begin{array}{c}\text { Score in virion } \\
\text { cores from }\end{array}$ \\
& $\begin{array}{c}\text { Sup- Act. N-Act. } \\
\text { T1 THP1 THP1 }\end{array}$ & Known role in HIV-1 replication \\
& &
\end{tabular}

\section{DNA Binding: Chromatin Organization, Replication, Topoisomerases}

Regulator of chromosome $\quad$ RCC2 3.321 .78 condensation 2

RCC proteins interact with Rac1 and Arf6 subnetworks and limit signaling required for membrane protrusion and delivery [99]; RCC2 acts as a Rac1 guanine nucleotide exchange factor (GEF); RCC1 is involved in HIV-1 RNA nuclear export through activation of RanGAP [100] and hence facilitates dissociation of RNA nuclear export complex [101].

RNA Binding: Structure Organization, Modification, Splicing, Transport
Helicase like protein 2

DEAD/H box polypeptide 3
DDX3X $2.05-$
Member of DEAD box RNA helicases that is implicated in alteration of RNA secondary structure such as translation initiation, nuclear and mitochondrial splicing, and ribosome and spliceosome assembly. RNAi knockdown of DDX3 suppresses HIV-1 viral replication [102]; interaction of DDX3 with Rev/CRM1 is important for nuclear export of non-spliced HIV-1 RNA [103].

RNA-dependent helicase p72 - DDX17 6.36 - _ Members of ATP-dependent DEAD box RNA helicases, potentially involved in interaction with HIV-1 RNA.
DEAD box poly

RNA helicase II/Gu protein - DEADDDX21 box polypeptide 21

ATP-dependent RNA helicase A - DHX9 $6.36 \quad 6.09 \quad 27.18$ DEAD box protein 9

\begin{tabular}{|c|c|c|}
\hline $\begin{array}{l}\text { Heterogeneous } \\
\text { ribonucleoprotein A1 }\end{array}$ & nuclearHNRNPA1- & 1.92 \\
\hline $\begin{array}{l}\text { Heterogeneous } \\
\text { ribonucleoprotein F }\end{array}$ & nuclearHNRNPF 3.47 & - \\
\hline $\begin{array}{l}\text { Heterogeneous } \\
\text { ribonucleoprotein } \mathrm{H} 1\end{array}$ & nuclearHNRNPH13.04 & - \\
\hline $\begin{array}{l}\text { Heterogeneous } \\
\text { ribonucleoprotein M isoform }\end{array}$ & $\begin{array}{l}\text { nuclearHNRNPM } 1.9 \\
\text { n b }\end{array}$ & - \\
\hline $\begin{array}{l}\text { Heterogeneous } \\
\text { ribonucleoprotein R }\end{array}$ & nuclearHNRNPR 6.31 & - \\
\hline
\end{tabular}

Nonsense-mediated decay (NMD)UPF1 $5.656 .48 \quad 6.32$ factor

$\beta$ Actin

Tubulin a 1

Tubulin a 6

Tubulin $\beta 5$

Tubulin $\beta 3$

Tubulin $\beta 1$

Tubulin $Y 1$

Dynein

ARP3 actin-related protein 3ACTR3 - 9.52 homolog (yeast)

TUBB1 $\quad 13.3-\quad 22.5$

TUBG1 - $\quad 4.96$
ACTBL2 60.1235.05 99.59 Actin microfilaments are important for RTC formation and RTC transport in cytoplasm [1]; interaction with NC domain of Gag is required for HIV-1 assembly [109].

TUBA1A 69.3958.56 66.49 Microtubules are shown to be important for RTC cytoplasmic trafficking $[18,110]$

TUBA1C 57.1141 .3961 .72

TUBB $\quad 29.8227 .8549 .68$

TUBB3 $\quad 13.849 .07 \quad 30.56$

DYNC1H1- $\quad 11.6810 .11$ Dynein motor and late endosomes are involved in viral RNA trafficking [112] and transport of RTC toward the nucleus [18].

\section{Cytoskeleton Regulation}

Major constituent of the ARP2/3, a 7 subunit complex, responsible for actin polymerization [113]. The complex is required for early phase of HIV-1 replication [114]. 


\section{Table 3 Previously discovered viral proteins with a known role in HIV-1 Replication ${ }^{\text {a }}$ (Continued)}

\begin{tabular}{|c|c|c|c|c|c|}
\hline \multicolumn{6}{|r|}{ Nuclear Import } \\
\hline $\begin{array}{l}\text { Transportin 3; importin-SR; } \\
\text { importin 12; transportin SR2 }\end{array}$ & TNPO3 & 1.0 & - & - & $\begin{array}{l}\text { Impotin- } \beta \text { family member, binds catalytic core domain close to the } \mathrm{N} \text { terminus of IN } \\
\text { and promotes nuclear entry of PICs }[115,116] ; \text { might serve as a chaperone that } \\
\text { associates with PIC post-entry to guide it through nuclear pore }[117] \text {. }\end{array}$ \\
\hline Karyopherin a2; importin a1) & KPNA2 & - & - & 7.91 & $\begin{array}{l}\text { Directly interacts with central core domain of HIV-1 integrase, facilitates PIC nuclear } \\
\text { import [118-120]. }\end{array}$ \\
\hline Karyopherin $\beta 2$; importin $\beta 2$ & TNPO1 & - & 3.63 & 1.95 & \multirow{2}{*}{$\begin{array}{l}\text { Importin a/ } \beta \text { heterodimer interacts with HIV-1 integrase and probably MA protein } \\
\text { and Vpr to translocate PIC into the nucleus [121] }\end{array}$} \\
\hline Karyopherin $\beta 1$; nuclear facto & KPNB1 & - & - & 8.02 & \\
\hline
\end{tabular}

importin 90

\begin{tabular}{|c|c|c|c|c|c|}
\hline RANBP21/exportin 5 (Exp5) & XPO5 & 5.5 & - & 6.87 & $\begin{array}{l}\text { Association of RanBP1 and } 2 \text { with Rev-CRM1-RanGTP complex has been shown [122], } \\
\text { thus RanBP is required for dissociation of nuclear export complex during HIV-1 } \\
\text { RNA nuclear export [101]. }\end{array}$ \\
\hline & & & & & Vesicular Transport \\
\hline CLTC protein - clathrin & CLTC & 37.6 & 7.7 & 7 & $\begin{array}{l}\text { Clathrin is incorporated in HIV-1 particles probably through interaction with Pol, } \\
\text { especially IN domain [32]; it facilitates the accurate morphogenesis of infectious } \\
\text { particles probably by contribution to spatial organization of Gag and Pol proteins and } \\
\text { proteolytic processing of virion components during particle assembly [5]. }\end{array}$ \\
\hline Rab5C GTP protease & RAB5C & - & 6.78 & 6.58 & Rab GTP proteases are important for vesicular trafficking. They are activated by \\
\hline Rab7A GTP protease & RAB7A & 8.89 & 9.08 & 21.97 & $\begin{array}{l}\text { guanine nucleotide exchange factor (GEF), RCC2 protein revealed in HIV-1 cores can } \\
\text { act as a GEF. Rab11 is important for HIV-1 production [123]; Rab1 potentially }\end{array}$ \\
\hline Rab8A GTP protease & RAB8A & 7.91 & 6.78 & 6.58 & associates with HIV-1 Rev and is involved in nuclear export of viral RNA [124]; \\
\hline Rab11A GTP protease & RAB11A & - & - & 9.31 & involved in viral entry [58]. \\
\hline $\begin{array}{l}\text { Programmed cell death } 6 \\
\text { interacting protein; HP95; } \\
\text { AIP1/ALIX }\end{array}$ & PDCD6IP & 6.43 & 13.62 & 29.94 & $\begin{array}{l}\text { Alix/HP95 is a protein implicated in endosomal organization and virus budding; } \\
\text { overexpression results in cytoplasmic vacuolization, which may be partially } \\
\text { responsible for protection against cell death. AIP1/ALIX is a binding partner for HIV-1 } \\
\text { Gag L-domain and other budding network proteins (Tsg101) functioning in virus } \\
\text { budding [125]. }\end{array}$ \\
\hline
\end{tabular}

\section{Nuclear Export}

\section{Intracellular Trafficking}

TNFAIP3 interacting protein 1; $\quad$ TNIP1 $1.0 \quad$ - $\quad$ - $\quad$ An ERK2 binding protein, Naf1, attenuates EGF/ERK2 nuclear signaling, binds HIV-1 HIV-1 Nef interacting protein; NAF1 Nef and increases cell surface CD4 expression [126]. ERK2 interacts with HIV-1 matrix, packaged into virions and responsible for MA phosphorylation [24].

\section{Chaperones/Molecular Folding}

\begin{tabular}{|c|c|c|c|c|}
\hline Hsp70 protein 8 & HSPA8 & 7.8526 .4 & 31.35 & Heat shock protein 70 family members are shown to be incorporated in HIV-1 \\
\hline Hsp70 protein 9 (mortalin) & HSPA9 & 5.75 & - & $\begin{array}{l}\text { particles. This is important for subsequent viral cDNA synthesis }[11,127] \text {; they can also } \\
\text { interfere with Vpr in HIV-1 nuclear import in macrophages }[128,129] \text {. }\end{array}$ \\
\hline Cyclophilin A, CyPA & PPIA & 22.3520 .00 & 7.68 & $\begin{array}{l}\text { incorporates into virions via binding to the CA domain of Pr55Gag [23]. The role of } \\
\text { CA-bound CyPA is still unclear [48] It is critical for protection and stabilization of } \\
\text { HIV-1 cores as a chaperone [49] and is probably involved in PIC nuclear transport [31] }\end{array}$ \\
\hline
\end{tabular}

\footnotetext{
a Proteins are listed by function category.

${ }^{\mathrm{b}}$ Full Protein name as listed in NCBI Protein database (http://www.ncbi.nlm.nih.gov/protein).

' Official Gene Symbol as listed by HGNC.

${ }^{d}$ The Xcorr values of each protein in different viral core samples are shown; if protein was not present in the virion core from a specific producer cell type, the Xcorr is not shown.

e Protein function within the cell is listed, along with known implicated function(s) in HIV-1 replication.
}

the other factors, such as Hsp70, CLTC protein/clathrin and Rab GTP proteases, their important role in the molecular organization of mature virions and probably viral entry into the target cells has been proposed earlier $[5,11,32,33,58]$. Here, we focus on the proteins identified in the core structures of HIV-1 virions assembled in different cell types. These proteins can be potentially involved in post-entry stages of the viral replication.

The HIV-1 morphogenesis is known to be different in $\mathrm{T}$ lymphocytes and myeloid cells. In $\mathrm{T}$ cells, the viral particle budding and assembly have been shown to take place directly at the plasma membrane (reviewed in [131]), whereas in macrophages, earlier studies detected assembling HIV-1 particles in the late endosomes [132] (reviewed in [131]) or in internally sequestered plasma membrane domains that contain late endosomal markers but are connected to the cell surface [133]. Recent reports revealed an extensive tubular network and large sheet-like structures which extended to the cell surface from vesicular compartments and contained HIV-1 
virions, released into the extracellular media [134,135]. Indeed, the cores of model MDM-derived virions contained twelve vesicular trafficking-associated proteins, whereas only six were detected in the T cell-derived viral cores. The larger proportion of cytoskeleton and cytoskeleton regulatory proteins in the cores of virions assembled in THP1 cells than in Sup-T1-derived cores may be dependent on the abundance of these proteins in producer cells. Uninfected THP1 cells contain larger amounts of actin and $\beta$ tubulin than Sup-T1 (Figure 3A), suggesting that other cytoskeleton and associated cytoskeleton regulatory proteins may also be more abundant in these myeloid cells; hence, increasing the probability that the virus will hijack this subset of proteins. Our data suggest that the unique core-incorporated proteins, which are different in the viruses assembled in different cell types, are mostly indiscriminately hijacked during virion assembly and likely not important for subsequent infection.

The group of forty two cellular proteins identified in the cores of virions produced by all types of cells contains at least thirteen proteins whose involvement in different stages of HIV-1 infection has been shown previously (Table 2 and 3). On the other hand, many proteins within this group have never been found to be implicated in any infection event. Meanwhile, incorporation of these proteins into the viral cores from different types of producer cells suggests that at least some of them may be important for successful infection. For instance, within the functional category of vesicular trafficking-associated proteins, the member of ESCRT pathway AIP1/ALIX detected in all our core preparations has been shown earlier to be interacting with HIV$1 \mathrm{Gag}$ late domain and to be important for the release of viral particles $[125,136]$. Clathrin has also been found to be abundant in HIV-1 viral particles and important for the correct assembly and maturation of viral particles through the regulation of proteolytic processing of virion components [5,32]. Members of the RAB family of proteins were found to be important for different steps of HIV-1 particle assembly and probably RNA incorporation $[112,123,124]$ (Table 3). Available data suggest that the proteins of this group are important factors of assembly and maturation of the viral particle and get into the viral cores in association with Gag and GagPol proteins or viral RNA. Some of the factors of vesicular trafficking may be potentially involved in the early stage of HIV-1 infection: the functional genomic screening of factors involved in HIV-1 infection showed that the vesicular RAB6A protein is important for the late phase of reverse transcription in infected cells [58].

The cytoskeletal proteins were also abundant in all core preparations, however, the role of these proteins in HIV-1 virions is still questionable. The actin microfilaments form the plasma membrane cortex, and both actin and microtubular networks are involved in HIV-1 particle assembly $[111,112,137]$, so that the proportion of these proteins in viral particles may be up to $15 \%$ of the molar level of Gag [94]. Actin is packaged in the virions probably in association with the NC domain of Gag $[111,137,138]$. Thus, actin and actin-associated proteins coronin, moesin, filamin, and FLII can get into the viral cores due to the actin interaction with Gag or GagPol. However, involvement of these virion-packaged molecules in post-assembly events of the virus life cycle has not been shown [12]. Our data indicate that the ratio of $\beta$ tubulin between the viral cores reproduced the concentration ratio of this protein between the producer cells, suggesting the capturing, but not specific incorporation, of this cytoskeletal protein into assembling virions. On the contrary, the cytoskeleton regulation proteins were found to be mostly different in the viral cores from different cell types, which may reflect variability of the profiles of these proteins in virus-producing cells. Some of them, particularly Hsp27, a protein containing a nuclear localization signal [139] and found in the cores of virions from all cell types, can be potentially involved in post-entry steps of infection, although the role of this protein in viral replication remains unknown.

The other category of proteins abundant in HIV-1 viral cores is the molecular chaperones. The profiles of these proteins are very similar in all analyzed samples. Indeed, Hsp27, Hsp40 (DnaJ) co-chaperone, Hsp70, Hsp90, numerous members of TCP1 (Hsp60) tetradecameric complex, as well as peptidylprolyl isomerase cyclophilin A were found in all core preparations (Table 2). Previously, these proteins were identified in purified samples of whole HIV-1 virions and Gag preparations [4,10,23]. Hsp70 was also found in HIV-2, $\operatorname{SIV}_{\text {MAC }}$ and $\operatorname{SIV}_{\mathrm{AGM}}[11,56]$. Since the major function of these proteins is to regulate folding of newly synthesized polypeptides, facilitate intracellular protein transport and assemble multisubunit protein structures $[140,141]$, they likely play an important role in HIV-1 particle assembly, processing and folding of the viral proteins during virion core maturation and maintain structural integrity of the viral core and RTCs $[11,33,49]$. The early RTC functions, especially organization of reverse transcription, may also depend on the proper activity of incorporated chaperones.

The RNA-binding proteins represent the most diverse group of cellular factors in viral cores. Although we identified 29 RNA-binding proteins in the core preparations, only four of them were found in all core samples (Table 2). These are (1) regulator of nonsense transcript stability (UPF1), (2) ATP-dependent RNA helicase A (RHA or DHX9), (3) small nuclear ribonucleoprotein component (Snrp116 or EFTUD2), and RNA helicase hBrr2 $200 \mathrm{kDa}$ (SNRNP200 or HELIC2). The role of the first two factors in HIV-1 infection was thoroughly characterized before. The UPF1 protein, RNA helicase from the 
SFI superfamily, involved in translation of Gag polypeptide, was found in virus-producing cells in association with HIV1 ribonucleoprotein (RNP) along with Pr55Gag, viral RNA and cellular protein Staufen 1 [108]. Thus, UPF1 can be packaged in the virions in association with both Gag and the viral genomic RNA. RNA helicase A (RHA), a member of the DEAD family of proteins which are capable of unwinding the double-stranded RNA structure, was earlier found to be associated with HIV-1 Gag and incorporated into HIV-1 virions in an RNA-dependent manner. Packaging of this protein into HIV-1 virions was important for endogenous reverse transcription [10]. Jeang and Yedavalli suggested that RHA incorporated into HIV-1 viral cores might be important for the reverse transcription in RTCs [95]. A recent study that revealed an important role of this enzyme in the annealing of tRNA ${ }^{\text {Lys3 }}$ primer [73], confirmed this suggestion. Two other proteins, SNRNP200 (member of the family of U5 DEXH-box RNA helicases) and Snrp116 (U5 snRNP specific protein, $116 \mathrm{kD}$ ), are both members of the U5 group of small nuclear RNA proteins, the spliceosome components, and have not been detected in HIV-1 virions before. Since these proteins are known as important components of splicing machinery required for a spliceosome catalytic activity $[142,143]$, they can be associated with HIV-1 pre-mRNA and remain associated with a mature viral RNA molecule.

Interestingly, our analysis showed higher level of DHX9 (RHA) and SNRNP200 (HELIC2) in the cores of virions assembled in T cells, as compared with the viral cores from the monocyte and MDM models, which did not correlate with the abundance of these proteins in producer cells. Since we did not find significant differences in the RNA and CA protein count between the virions from analyzed cells, observed differences suggest that the mechanism of incorporation of these proteins into the virions (binding to viral RNA or interaction with Gag or/and GagPol) is more effective and likely selective in $\mathrm{T}$ lymphocytes, than in monocyte and MDM model cells. Because of importance of RNA helicase A for the reverse transcription in HIV-1 virions and RTCs, we expect that SNRNP200 protein may also be involved in cDNA synthesis or accumulation.

Analysis of earlier published genome-wide screens performed by Warrilow and co-authors [22] to select the host factors potentially implicated in HIV reverse transcription showed that the proteins involved in DNA replication, transcription and repair, as well as proteins of the ubiquitin-proteasome pathway may also be important. Within the 17 DNA-binding proteins detected in our core preparations, only two, ATP-dependent DNA helicase II (XRCC5 or Ku80) and TATA binding protein interacting protein $49 \mathrm{kDa}$ (RUVBL1 or Pontin52), were found in the core of all virions. Two other proteins, minichromosome maintenance complex component 5
(MCM5 or CDC46) and regulator of chromosome condensation protein 2 (RCC2), were identified only in SupT1 and activated THP1 cells (Table 2), although Western blot showed presence of MCM5 also in non-activated THP1. The protein RUVBL2 (Reptin52) was not identified by MS/MS in activated THP1, but the fact that in cells this DNA helicase is complexed with the closely related RUVBL1 protein in hetero-dodecamers [144] suggests incorporation of this protein in the virions from all studied cells. Our analysis showed that among DNA binding proteins present in the viral cores from different cell types only XRCC5 and especially MCM5 displayed an increased level of incorporation from the T cells, similar to RNAbinding DHX9 and SNRNP200, whereas core incorporation of RUVBL1 and RUVBL2 reproduced their level in virion-producing Sup-T1 and THP1 cells. The DNA helicase MCM5, a member of the MCM family of chromatin-binding proteins is involved in the initiation of DNA replication and was found to be upregulated during the transition from the G0 to G1/S phase of the cell cycle (RefSeq database). Interaction of this protein with HIV has not been shown before. Another DNA helicase, XRCC5 or Ku80, which is involved in repairing DNA double-strand breaks, was earlier found to be important for viral cDNA circularization, nuclear import and integration $[145,146]$. However, this function was shown for the protein expressed in the infected target cells, but not for virion-incorporated Ku80. Packaging of both MCM5 and XRCC5 (Ku80) DNA helicases in all viral cores and their high levels in the cores of $\mathrm{T}$ lymphocyte-derived virions suggest that the core-incorporated molecules of these proteins can also be involved in processes associated with cDNA processing and/or integration during post-entry steps of infection, especially in T cells.

Within the group of ubiquitin-proteasome pathway associated proteins a total of 9 proteins were detected; three of them were identified in viral cores from all producer cells (Table 2). Earlier, numerous $26 \mathrm{~S}$ proteasomeassociated proteins were found in HIV-1 and SIV particles $[4,56]$. Involvement of the ubiquitin-proteasome system in the budding of lentiviral particles was shown earlier (reviewed in [147]). Since all major domains of the membrane-associated HIV-1 Gag molecules have been shown to be ubiquitinated during virion budding [148], the ubiquitination factors could package into virions in association with Gag and then get into the viral cores. However, the role of virion-associated factors of the ubiquitin-proteasome system in the early steps of HIV-1 infection is unknown.

\section{Conclusions}

Taken together, results of our study indicate that the profile of host cell proteins packaged in the cores of HIV-1 virions depends on the type of producer cell. High 
abundance of certain proteins in the cell increases the probability of their capturing by the virions and hence their presence in the viral cores. However, certain members of functional groups of DNA- and RNA-binding proteins, molecular chaperones, cytoskeletal, vesicular trafficking-associated and ubiquitin-proteasome pathwayassociated proteins were found in the cores of virions from all analyzed cells, suggesting that their incorporation is non-random and that they can be directly or indirectly involved in either the virus assembly/budding or early infection events. Our findings that the abundance of cellular proteins DHX9, (RHA) SNRNP200, MCM5, and XRCC5 (Ku80) within virus-producing cells did not correlate with the abundance seen in cores of produced virions, specifically their unexpected higher packaging in $\mathrm{T}$ cells, suggests that the incorporation of these factors in T lymphocytes is more efficient than in myeloid cells. These differences may be associated with variability of localization of these host proteins relative to the sites of virion assembly in different cell types and/or with different localization of virion assembly complexes. The host factors abundant in the viral cores may play a role in subsequent steps of HIV-1 infection, specifically in T cells. Further analysis of the role of these proteins in viral replication might reveal new mechanisms of the modulation of HIV infection by the host proteins and identify new targets for antiretroviral therapeutic interventions.

\section{Methods}

\section{Cells and viruses}

The acute monocytic leukemia cell line THP1 (from S. Tsuchiya) and T lymphoblastoma Sup-T1 cells (from James Hoxie) were provided by the NIH AIDS Research \& Reference Reagent Program. The human kidney fibroblasts $293 \mathrm{~T} / 17$ was purchased from ATCC (Manassas, VA). All cells were maintained at $37^{\circ} \mathrm{C}$ and $5 \% \mathrm{CO}_{2}$ in $75 \mathrm{~cm}^{2}$ tissue culture flasks with RPMI-1640 culture media supplemented with $10 \%$ Fetal Bovine Serum, penicillin/streptomycin $(100 \mu \mathrm{g} / \mathrm{ml})$, and L-Glutamine.

The stocks of the HIV-1 virus pseudotyped with amphotropic murine leukemia virus envelope glycoprotein (MLV Env) for synchronized infection of THP1 and Sup-T1 cells were prepared by transfection of $293 \mathrm{~T} / 17$ cells with HIV-1 NL4-3 provirus-encoding plasmid [149] and pcDNA-Env(MLV) plasmid (kindly provided by Nathaniel Landau) at a 4:1 ratio using Metafectene transfection reagent (Biontex, Planegg, Germany). The cells were transfected in $75 \mathrm{~cm}^{2}$ tissue culture flasks; the plasmid DNA containing media was changed at $5 \mathrm{~h}$ post-transfection. After overnight incubation with fresh RPMI-1640, the media was changed again and the cells were cultured in fresh media for an additional $48 \mathrm{~h}$ at $37^{\circ} \mathrm{C}$ and $5 \% \mathrm{CO}_{2}$. Then, the supernatants were harvested, filtered through a $0.45-\mu \mathrm{m}$ filter and stored on wet ice at $4^{\circ} \mathrm{C}$ for $1-4$ days.

\section{Infection}

The viral suspensions were normalized according to their RT activity corresponding to $1 \times 10^{6} \mathrm{cpm}$ per $1 \times 10^{6}$ cells, mixed with Polybrene (Sigma) to a final concentration of $8 \mu \mathrm{g} / \mathrm{ml}$ and used for infection of approximately $200 \times 10^{6}$ viable Sup-T1 or THP1 cells by spinoculation [150]. Infection was performed in 6-well plates $\left(5 \times 10^{6}\right.$ cells per well) by centrifugation at $1000 \times \mathrm{xg}$ for $2 \mathrm{~h}$ at $18^{\circ} \mathrm{C}$. After a $2 \mathrm{~h}$ incubation at $37^{\circ} \mathrm{C}$ and $5 \%$ $\mathrm{CO}_{2}$, the cells were washed from the virus-containing media, re-suspended in RPMI-1640 (pre-warmed to $37^{\circ}$ C) and seeded in a regular (Sup-T1 and non-activated THP1) or polylysine-treated (THP1 for activation) $75 \mathrm{~cm}^{2}$ tissue culture flasks at a concentration of $4 \times 10^{6}$ cells per ml (Sup-T1, non-activated THP1) or of $1 \times 10^{6}$ cells per $\mathrm{ml}$ (THP1 for activation). To get activated THP1 cells, the PMA and vitamin $\mathrm{D}_{3}$ solutions were added to cells to a final concentration of $100 \mathrm{nM}$. Then, the cells were incubated at $37^{\circ} \mathrm{C}$ and $5 \% \mathrm{CO}_{2}$ for $72 \mathrm{~h}$.

\section{Concentration of virus and "spin-thru" isolation of viral cores}

Virus-containing culture media from infected Sup-T1, activated and non-activated THP1 cells, as well as the media from the same types of non-infected cells (control) were harvested at $72 \mathrm{~h}$ after incubation with virus (or equivalent volume of the virus-negative culture media) and purified from cell debris by being centrifuged at 2,500 rpm and $4^{\circ} \mathrm{C}$ for 5 minutes and filtered through $0.45 \mu \mathrm{m}$ syringe filters. Then, filtered samples were centrifuged at $100,000 \mathrm{xg}$ and $4^{\circ} \mathrm{C}$ for $3 \mathrm{~h}$ through $2 \mathrm{ml}$ cushions of $30 \%$ sucrose in STE buffer $(10 \mathrm{mM}$ Tris- $\mathrm{HCl}$ [pH 7.4], $100 \mathrm{mM} \mathrm{NaCl}$, and $1 \mathrm{mM}$ EDTA) in a Beckman SW-41 rotor. The pellets were re-suspended in $300 \mu \mathrm{l}$ of STE buffer and the viral cores were then isolated by "spin-thru" purification as described earlier [63-66]. Briefly, $3.8 \mathrm{ml}$ of a 30-50\% linear density gradient of sucrose in STE buffer was overlaid with $1 \mathrm{ml}$ of $15 \%$ sucrose containing $1 \%$ Triton X-100 and then covered with a $0.4-\mathrm{ml}$ cushion of $7.5 \%$ sucrose in STE. The HIV-1 positive and negative samples, concentrated through 30\% sucrose and resuspended in STE $(0.3 \mathrm{ml})$ were carefully layered on top of the $7.5 \%$ sucrose layer and centrifuged in a Type $100 \mathrm{Ti}$ rotor (Beckman Coulter) at $100,000 \mathrm{xg}$ and $4^{\circ} \mathrm{C}$ for $16-18 \mathrm{~h}$. The pellets were re-suspended in $26 \mu \mathrm{l}$ of STE buffer and replaced to polypropylene, non-siliconized Eppendorf microtubes; $4 \mu \mathrm{l}$ aliquots were set aside for the p24 ${ }^{\mathrm{CA}}$ ELISA assay. The CA p24 ${ }^{\mathrm{Gag}}$-normalized suspensions of HIV-1 cores and control suspensions were subjected to SDS-PAGE protein separation for subsequent LC-MS/MS analysis, 
Western blotting, or to In-solution protein digestion with trypsin for the LC-MS/MS analysis of unseparated protein samples.

In order to test purity of the "spin-thru" isolated cores from undestroyed viral particles, $400 \mu \mathrm{l}$ aliquots of the suspensions of viral cores and concentrated whole virions were separately subjected to centrifugation in a $30-70 \%$ sucrose gradient for $5 \mathrm{~h}$ at $125,000 \mathrm{xg}$ and $4^{\circ} \mathrm{C}$ in a SW-60Ti rotor (Beckman Coulter). Ten fractions of the gradient (each $400 \mu \mathrm{l}$ ) were then collected from the bottom of the tubes and densities were determined. All fractions were dialyzed versus $1 \mathrm{~L}$ of ice-cold PBS using Tube-O-DIALYZER 1 kDa MEDI Kit (G Biosciences, St. Louis, MO) according to the manufacturer's protocol and then applied for p24 enzyme-linked immunosorbent assay using Alliance HIV-1 p24 ELISA Kit (PerkinElmer, Waltham, MA).

Additionally, electron microscopy (EM) was applied to test purity of the viral and core preparations. For EM, the virions concentrated through $30 \%$ sucrose and "spinthru"-purified core preparations were resuspended in $20 \mu \mathrm{l}$ of STE buffer, incubated 20 minutes on formware carbon film-coated 100 square mesh nickel grids (Electron Microscopic Sciences) at room temperature, and then incubated with $4 \%$ glutaraldehyde fixing solution for 10 minutes. After five-time wash in molecular grade water (Mediatech, Manassas, VA), samples were stained with $2 \%$ uranyl acetate. For analysis of virion structure, the pellets of virions after centrifugation through $30 \%$ sucrose were washed twice with PBS and then fixed with $4 \%$ glutaraldehyde for $4 \mathrm{~h}$. The preparations were further fixed with $2 \% \mathrm{OsO}_{4}$ for $2 \mathrm{~h}$, dehydrated with a graded series of ethanol dilutions ranging from 25\% to $100 \%$ and then embedded in Araldite 502 resin. Ultrathin sections were contrasted with $2 \%$ uranyl acetate in methanol and 1\% lead citrate. All preparations were examined on a JEOL JEM 1200 transmission electron microscope operating at $100 \mathrm{kV}$.

\section{Western blot analysis}

The aliquots of the lysates of HIV-1 infected Sup-T1 and THP1 cells, the virus samples and culture media from non-infected cells taken before and after the "spin-thru" isolation were subjected to SDS-PAGE, subsequently transferred to a PVDF membrane and then detected using anti-HIV-1 p24 (24-3) mouse monoclonal antibody and human HIV immunoglobulin (HIV-IgG) from NIH AIDS Research \& Reference Reagent Program; anti-RNA Helicase A (ab70777) rabbit polyclonal antibody from Abcam; anti-CD45, clone F10-89-4 monoclonal antibody from Millipore (Temecula, CA); monoclonal anti-Actin clone AC-40 from Sigma; anti- $\beta$ tubulin (D-10), anti-Reptin 52 (D-6), anti-Ku80 (B-1) and anti-MCM5 (G-1) mouse monoclonal antibodies from SantaCruz Biotechnology (Santa Cruz, CA); antiHELIC2 (N-20) and anti-Pontin $52(\mathrm{~N}-15)$ goat polyclonal antibodies also from Santa Criz. Specific bands were visualized by ECL (Thermo Scientific, Rockford, IL). Quantification of the Western blotting results was performed using ImageJ software.

\section{Gel separation of proteins, protein digestion and peptide extraction}

The volumes of viral core suspensions, each containing $400 \mathrm{ng}$ of $\mathrm{p} 24^{\mathrm{CA}}$ protein, and control suspensions taken in twofold excess were mixed with equal volumes of Laemmli Sample Buffer (BioRad, Hercules, CA) containing $5 \% \beta$ mercaptoethanol, heated in boiling water for 2 minutes and applied for SDS-PAGE protein separation. Separation of proteins was performed in $12.5 \%$ Tris$\mathrm{HCl}$ Criterion Precast Gel (BioRad) at $100 \mathrm{~V}$ and $4^{\circ} \mathrm{C}$ for $2-2.5 \mathrm{~h}$. The gel was stained in $0.1 \%(\mathrm{wt} / \mathrm{v})$ Coomassie (BioRad) solution (40\% methanol (v/v), 10\% acetic acid $(\mathrm{v} / \mathrm{v})$ in water with $1 \mathrm{~g} / \mathrm{L}$ of Brilliant Blue R-250) for $1 \mathrm{~h}$ at room temperature. After 7-8 washes in de-staining solution (contains the same components, as staining solution, except Brilliant Blue R-250) the gel was replaced to water, and each lane was sectioned into 10 contiguous pieces, which were subjected to the "in-gel" proteolysis according to the modified previously published protocol [151] Briefly, acetonitrile (ACN) dehydrated gel pieces were rehydrated in $10 \mathrm{mM}$ DTT and incubated at $60^{\circ} \mathrm{C}$ for $1 \mathrm{~h}$. After cooling at room temperature, the gel slices were incubated with $50 \mathrm{mM}$ iodacetamide for $1 \mathrm{~h}$ at room temperature in the dark for alkylation of proteins. After the second dehydration, a $15 \mu \mathrm{l}$ dose of Trypsin Gold (Promega, Madison, WI) solution $(20 \mu \mathrm{g} / \mathrm{ml})$ in $40 \mathrm{mM} \mathrm{NH} \mathrm{HCO}_{3} / 10 \% \mathrm{ACN}$ was added to each of the gel pieces. After $1 \mathrm{~h}$ saturation at $4^{\circ} \mathrm{C}$, the pieces were incubated at $37^{\circ} \mathrm{C}$ overnight. The resulted peptides were extracted three times: (1) with $25 \mathrm{mM}$ of $\mathrm{NH}_{4} \mathrm{HCO}_{3}$ : ACN (1:1); (2) 5\% formic acid (FA); (3) 5\% FA:ACN (1:1). After pooling all the extracts together, samples were purified through ZipTip pipette tips C18 (Millipore), eluted with $30 \mu \mathrm{l}$ of $0.1 \%$ trifluoroacetic acid (TFA) in $80 \% \mathrm{ACN}$ and subjected to HPLC separation and MS/MS analysis.

For "in-solution" protein digestion, the suspensions of HIV-1 cores after "spin-thru" centrifugation were treated with $10 \mathrm{mM}$ DTT $\left(60^{\circ} \mathrm{C}\right.$ for $\left.1 \mathrm{~h}\right)$ and $150 \mathrm{mM}$ iodacetamide ( $1 \mathrm{~h}$ at room temperature in the dark) in $20 \mathrm{ul}$ of STE buffer. The protein samples were then mixed with $100 \mu \mathrm{l}$ of $200 \mathrm{mM}$ ammonium bicarbonate and treated with $200 \mathrm{ng}$ of Trypsin Gold (Promega) at $37^{\circ} \mathrm{C}$ overnight. The resulted peptides were dried in SpeedVac, resuspended in water, purified through ZipTip pipette tips C18 as described above and then subjected to HPLC separation and MS/MS analysis. 


\section{HPLC-MS/MS of tryptic digests and database search}

The peptides in each sample were separated by microcapillary reversed-phase liquid chromatography (HPLC), coupled online to an ion trap mass spectrometer Thermo LTQ Orbitrap XL. The mass spectrometer was operated in a data-dependent MS/MS mode using a normalized collision-induced dissociation (CID) energy of 35\%. The CID spectra were compared against those of the EMBL non-redundant protein database. Only peptides having cross-correlation $\left(X_{\text {corr }}\right)$ cutoffs of 2.6 for $[\mathrm{M}+2 \mathrm{H}]^{2+}, 3.0$ for $[\mathrm{M}+3 \mathrm{H}]^{3+}$ and higher charge state were considered. These SEQUEST criteria thresholds resulted in a 1-2\% of False Descovery Rate. The proteome analysis of the spectra was made by Proteome Discoverer 1.2 software (Thermo Fisher Scientific). The protein profiles of the samples of viral cores were compared with identically prepared samples from non-infected cells. The sub-cellular localization and function of each filtered protein was determined using gene ontology (GO) information obtained from cross-referencing each protein's Swiss-Prot accession number to the GO localization information available on the NCBI protein database (http://www.ncbi. nlm.nih.gov/sites/entrez?db=Protein) and The Human Protein Atlas database (www.proteinatlas.org). The involvement of the proteins in known cellular pathways associated with major biological processes such as cell cycle, intracytoplasmic transport, cytoplasm organization, nuclear transport, chromatin structure maintenance/regulation, RNA splicing and reorganization, transcription, apoptosis, proteasomal degradation, etc. were assessed using NCBI RefSeq database (www.ncbi.nlm.nih.gov/ RefSeq/) and DAVID Bioinformatics Resources 6.7 (NIAID NIH) (http://david.abcc.ncifcrf.gov).

\section{RNA purification and RT reaction}

RNA was purified from suspensions of "spin-thru" purified viral cores containing $250 \mathrm{ng}$ of $\mathrm{p} 24^{\mathrm{CA}}$ using TRI Reagent-LS (MRC, Cincinnati, OH) according to the manufacturer's protocol. A total of $0.5 \mu \mathrm{g}$ of RNA from the RNA fraction was treated with $0.25 \mathrm{mg} / \mathrm{ml}$ DNase I RNase-free (Roche, Mannheim, Germany) for 60 minutes in the presence of $5 \mathrm{mM} \mathrm{MgCl}$, followed by the heat inactivation at $65^{\circ} \mathrm{C}$ for 15 minutes. A $250 \mathrm{ng}$ aliquot of total RNA was used to generate cDNA with the GoScript Reverse Transcription System (Promega, Madison, WI) using oligo-dT reverse primers.

\section{DNA isolation and quantitative real-time PCR}

Lysates of HIV-1 infected (72 h p.i.) Sup-T1, activated and non-activated THP1 cells were normalized to the total protein count using DC Protein Assay (BioRad) following manufacturer's protocol. The total DNA was isolated using an IsoQuick Nucleic Acid Extraction Kit (ISC BioExpress, Kaysville, UT) following manufacturer's recommendations. After isolation, the cellular DNA samples were analyzed by quantitative TaqMan real-time PCR to quantify chrosomal DNA. Set of primers specific for the $\beta$-globin gene has been used: forward primer BGF1 (5'-CAACCTCAAACAGACACCATGG-3'), reverse primer BGR1 (5'-TCCACGTTCACCTTGCCC-3'), and probe BGX1 (5'-FAM-CTCCTGAGGAGAAGTCTGCCGTTACTGCCTAMRA-3'). The $2 \mu \mathrm{l}$ aliquots of RT reaction mixtures of the RNA samples from isolated viral cores (see above) were diluted to 10-fold and 100-fold and subjected to quantitative real-time PCR analysis with the set of primers specific for late HIV-1 reverse transcription product as described earlier [152]. The primers FOR-LATE (5'-TGTGTGCCCG TCTGTTGTGT-3'), REV-LATE (5'-GAGTCCTGCGTCG AGAGATC-3'), and probe Lt-LTR-Prb (5'-FAM-CAGTGG CGCCCGAACAGGGA-TAMRA-3') recognized the positivestrand DNA, specific for the U5- $\Psi$ LTR region. PCR reactions were performed with PerfeCTa qPCR FastMix, UNG (Quanta Biosciences, Gaithersburg, MD) using 300 $\mathrm{nM}$ of each primer and $200 \mathrm{nM}$ of probe according to the manufacturer protocol. Serial dilutions of DNA from 8E5 cells (CEM cell line containing a single copy of HIV-1 LAV provirus per cell) were used as the quantitative standards. Real-time PCR reactions were carried out at least in triplicate using the PTC-200 Peltier Thermal Cycler with Chromo4 Continuous Fluorescence Detector (both from MJ Research) and Opticon Monitor 2.03 software.

\section{Additional file}

Additional file 1: Table S1: Overlapping and unique high scored cellular proteins within viral cores isolated from the virus produced by Sup-T1 cells infected with HIV-1 NL4-3 strain pseudotyped with MLV Env (blue symbols) or VSV-G (green symbols) envelope glycoproteins.

\section{Competing interests}

The authors declare that they have no competing interests.

\section{Author's contributions}

SS participated in the design of experiments, carried out most of the experiments, prepared samples for mass spectrometry and electron microscopy, analyzed data and contributed to manuscript preparation. YO performed LC-MS/MS data collection and analyzed raw mass spectrometry data. SN participated in the design of the study, supervised LC-MS/MS experiments and contributed to drafting of the manuscript. MB participated in the study design and coordination and contributed to manuscript preparation. SI conceived of the study, designed and coordinated experiments, participated in data analysis and prepared the manuscript. All authors read and approved the final manuscript.

\section{Acknowledgments}

The following reagents were obtained through the AIDS Research and Reference Reagent Program, Division of AIDS, NIAID, NIH: Sup-T1 cells from Dr. James Hoxie, THP1 from Dr. S. Tsuchiya, 8 E5 cells from Dr. Thomas Folks and anti-HIV-1 p24 mouse monoclonal antibody from Dr. Michael Malim. The HIV-1 proviral clone NL was a gift from Dr. Lee Ratner; pcDNA-Env(MLV) was kindly provided by Dr. Nathaniel Landau. Authors are grateful to Drs. Yetrib Hathout and Pawel Ciborowski for consultations on MS/MS data analysis, Drs. Fatah Kashanchi and David Jans for advice on the functional classification of HIV-associated proteins and to Dr. Tatyana Ammosova for advices on sample preparations for LC-MS/MS and Dr. Anastas Popratiloff for consultations and 
help with electron microscopy. This work was supported by the District of Columbia Developmental Center for AIDS Research (DC D-CFAR), an NIHfunded program 5P30AI087714-02 and the NIH grant from Research Centers in Minority Institutions (RCMI) Program of the Division of Research Infrastructure, National Center for Research Resources (RCMI-NIH 2G12RR003048). SS is a predoctoral student in the Microbiology and Immunology Program of the Institute for Biomedical Sciences at the George Washington University. This work is from a dissertation to be presented to the above program in partial fulfillment of the requirements for the Ph.D. degree.

\section{Author details}

'Department of Microbiology, Immunology and Tropical Medicine, George Washington University School of Medicine and Health Sciences, 2300 I Street NW, Ross Hall, Washington, DC 20037, USA. ${ }^{2}$ Department of Medicine, Center for Sickle Cell Disease, Howard University College of Medicine, 1840 7th StreetN.W, Washington, DC 20001, USA. ${ }^{3}$ Howard University College of Medicine, RCMI Proteomics Core Facility, 1840 7th StreetN.W, Washington, DC 20001, USA.

Received: 20 April 2012 Accepted: 15 July 2012

Published: 13 August 2012

\section{References}

1. Bukrinskaya A, Brichacek B, Mann A, Stevenson M: Establishment of a functional human immunodeficiency virus type 1 (HIV-1) reverse transcription complex involves the cytoskeleton. J Exp Med 1998, 188:2113-2125.

2. VerPlank L, Bouamr F, LaGrassa TJ, Agresta B, Kikonyogo A, Leis J, Carter CA: Tsg101, a homologue of ubiquitin-conjugating (E2) enzymes, binds the $L$ domain in HIV type 1 Pr55(Gag). Proc Natl Acad Sci USA 2001, 98: 7724-7729.

3. Martin-Serrano J, Zang T, Bieniasz PD: HIV-1 and Ebola virus encode small peptide motifs that recruit Tsg101 to sites of particle assembly to facilitate egress. Nat Med 2001, 7:1313-1319.

4. Chertova E, Chertov O, Coren LV, Roser JD, Trubey CM, Bess JW Jr, Sowder RC 2nd, Barsov E, Hood BL, Fisher RJ, et al: Proteomic and biochemical analysis of purified human immunodeficiency virus type 1 produced from infected monocyte-derived macrophages. J Virol 2006, 80: 9039-9052.

5. Zhang F, Zang T, Wilson SJ, Johnson MC, Bieniasz PD: Clathrin facilitates the morphogenesis of retrovirus particles. PLOS Pathog 2011, 7:e1002119.

6. Lawn SD, Butera ST: Incorporation of HLA-DR into the envelope of human immunodeficiency virus type 1 in vivo: correlation with stage of disease and presence of opportunistic infection. J Virol 2000, 74:10256-10259.

7. Tremblay MJ, Fortin JF, Cantin R: The acquisition of host-encoded proteins by nascent HIV-1. Immunol Today 1998, 19:346-351.

8. Mouland AJ, Mercier J, Luo M, Bernier L, DesGroseillers L, Cohen EA: The double-stranded RNA-binding protein Staufen is incorporated in human immunodeficiency virus type 1: evidence for a role in genomic RNA encapsidation. J Virol 2000, 74:5441-5451.

9. Chatel-Chaix L, Abrahamyan L, Frechina C, Mouland AJ, DesGroseillers L: The host protein Staufen 1 participates in human immunodeficiency virus type 1 assembly in live cells by influencing pr55Gag multimerization. J Virol 2007, 81:6216-6230.

10. Roy BB, Hu J, Guo X, Russell RS, Guo F, Kleiman L, Liang C: Association of RNA helicase a with human immunodeficiency virus type 1 particles. J Biol Chem 2006, 281:12625-12635.

11. Gurer C, Cimarelli A, Luban J: Specific incorporation of heat shock protein 70 family members into primate lentiviral virions. J Virol 2002, 76: 4666-4670.

12. Ott DE: Cellular proteins detected in HIV-1. Rev Med Virol 2008, 18:159175

13. Bukrinsky MI, Sharova N, McDonald TL, Pushkarskaya T, Tarpley WG, Stevenson M: Association of integrase, matrix, and reverse transcriptase antigens of human immunodeficiency virus type 1 with viral nucleic acids following acute infection. Proc Natl Acad Sci USA 1993, 90: 6125-6129.

14. Gallay P, Swingler S, Song J, Bushman F, Trono D: HIV nuclear import is governed by the phosphotyrosine-mediated binding of matrix to the core domain of integrase. Cell 1995, 83:569-576.
15. Connor Rl, Chen BK, Choe S, Landau NR: Vpr is required for efficient replication of human immunodeficiency virus type-1 in mononuclear phagocytes. Virology 1995, 206:935-944.

16. Aiken C, Trono D: Nef stimulates human immunodeficiency virus type 1 proviral DNA synthesis. J Virol 1995, 69:5048-5056.

17. Haffar OK, Popov S, Dubrovsky L, Agostini I, Tang H, Pushkarsky T, Nadler SG, Bukrinsky M: Two nuclear localization signals in the HIV-1 matrix protein regulate nuclear import of the HIV-1 pre-integration complex. J Mol Biol 2000, 299:359-368

18. McDonald D, Vodicka MA, Lucero G, Svitkina TM, Borisy GG, Emerman M, Hope TJ: Visualization of the intracellular behavior of HIV in living cells. J Cell Biol 2002, 159:441-452.

19. Yamashita M, Emerman M: Capsid is a dominant determinant of retrovirus infectivity in nondividing cells. J Virol 2004, 78:5670-5678.

20. Nisole S, Saib A: Early steps of retrovirus replicative cycle. Retrovirology 2004, 1:9.

21. Levin A, Loyter A, Bukrinsky M: Strategies to inhibit viral protein nuclear import: HIV-1 as a target. Biochim Biophys Acta 2011, 1813:1646-1653.

22. Warrilow D, Tachedjian G, Harrich D: Maturation of the HIV reverse transcription complex: putting the jigsaw together. Rev Med Virol 2009, 19:324-337.

23. Luban J, Bossolt KL, Franke EK, Kalpana GV, Goff SP: Human immunodeficiency virus type $1 \mathrm{Gag}$ protein binds to cyclophilins $\mathrm{A}$ and B. Cell 1993, 73:1067-1078

24. Cartier C, Deckert M, Grangeasse C, Trauger R, Jensen F, Bernard A, Cozzone A, Desgranges $C$, Boyer V: Association of ERK2 mitogen-activated protein kinase with human immunodeficiency virus particles. J Virol 1997, 71:4832-4837.

25. Jacque JM, Mann A, Enslen H, Sharova N, Brichacek B, Davis RJ, Stevenson M: Modulation of HIV-1 infectivity by MAPK, a virion-associated kinase. EMBO J 1998, 17:2607-2618.

26. Campbell EM, Hope TJ: Live cell imaging of the HIV-1 life cycle. Trends Microbiol 2008, 16:580-587.

27. Hulme $A E$, Perez $O$, Hope $T$ J: Complementary assays reveal a relationship between HIV-1 uncoating and reverse transcription. Proc Natl Acad SCl USA 2011, 108:9975-9980.

28. Arhel NJ, Souquere-Besse S, Munier S, Souque P, Guadagnini S, Rutherford S, Prevost MC, Allen TD, Charneau P: HIV-1 DNA Flap formation promotes uncoating of the pre-integration complex at the nuclear pore. EMBO 2007, 26:3025-3037.

29. Dismuke DJ, Aiken C: Evidence for a functional link between uncoating of the human immunodeficiency virus type 1 core and nuclear import of the viral preintegration complex. J Virol 2006, 80:3712-3720

30. Lee K, Ambrose Z, Martin TD, Oztop I, Mulky A, Julias JG, Vandegraaff N, Baumann JG, Wang R, Yuen W, et al: Flexible use of nuclear import pathways by HIV-1. Cell Host Microbe 2010, 7:221-233.

31. Schaller T, Ocwieja KE, Rasaiyaah J, Price AJ, Brady TL, Roth SL, Hue S, Fletcher AJ, Lee K, KewalRamani VN, et al: HIV-1 capsid-cyclophilin interactions determine nuclear import pathway, integration targeting and replication efficiency. PLoS Pathog 2011, 7:e1002439.

32. Popov S, Strack B, Sanchez-Merino V, Popova E, Rosin H, Gottlinger HG: Human immunodeficiency virus type 1 and related primate lentiviruses engage clathrin through Gag-Pol or Gag. J Virol 2011, 85:3792-3801.

33. Gurer C, Hoglund A, Hoglund S, Luban J: ATPgammaS disrupts human immunodeficiency virus type 1 virion core integrity. J Virol 2005, 79: 5557-5567.

34. Davis DA, Brown CA, Newcomb FM, Boja ES, Fales HM, Kaufman J, Stahl SJ, Wingfield P, Yarchoan R: Reversible oxidative modification as a mechanism for regulating retroviral protease dimerization and activation. J Virol 2003, 77:3319-3325.

35. Chatel-Chaix L, Boulay K, Mouland AJ, Desgroseillers L: The host protein Staufen 1 interacts with the Pr55Gag zinc fingers and regulates HIV-1 assembly via its N-terminus. Retrovirology 2008, 5:41

36. Guo F, Cen S, Niu M, Javanbakht H, Kleiman L: Specific inhibition of the synthesis of human lysyl-tRNA synthetase results in decreases in tRNA (Lys) incorporation, tRNA(3)(Lys) annealing to viral RNA, and viral infectivity in human immunodeficiency virus type 1. J Virol 2003, 77:9817-9822.

37. Selig L, Benichou S, Rogel ME, Wu LI, Vodicka MA, Sire J, Benarous R, Emerman M: Uracil DNA glycosylase specifically interacts with $\mathrm{Vpr}$ of both human immunodeficiency virus type 1 and simian 
immunodeficiency virus of sooty mangabeys, but binding does not correlate with cell cycle arrest. J Virol 1997, 71:4842-4846.

38. Willetts KE, Rey F, Agostini I, Navarro JM, Baudat Y, Vigne R, Sire J: DNA repair enzyme uracil DNA glycosylase is specifically incorporated into human immunodeficiency virus type 1 viral particles through a Vprindependent mechanism. J Virol 1999, 73:1682-1688.

39. Mansky LM, Preveral S, Selig L, Benarous R, Benichou S: The interaction of vpr with uracil DNA glycosylase modulates the human immunodeficiency virus type 1 In vivo mutation rate. J Virol 2000, 74:7039-7047

40. Chen R, Le Rouzic E, Kearney JA, Mansky LM, Benichou S: Vpr-mediated incorporation of UNG2 into HIV-1 particles is required to modulate the virus mutation rate and for replication in macrophages. J Biol Chem 2004, 279:28419-28425.

41. Harris RS, Bishop KN, Sheehy AM, Craig HM, Petersen-Mahrt SK, Watt IN, Neuberger MS, Malim MH: DNA deamination mediates innate immunity to retroviral infection. Cell 2003, 113:803-809.

42. Kaiser SM, Emerman M: Uracil DNA glycosylase is dispensable for human immunodeficiency virus type 1 replication and does not contribute to the antiviral effects of the cytidine deaminase Apobec3G. J Virol 2006, 80:875-882.

43. Guenzel CA, Herate C, Le Rouzic E, Maidou-Peindara P, Sadler HA, Rouyez MC, Mansky LM, Benichou S: Recruitment of the nuclear form of uracil DNA glycosylase into virus particles participates in the full infectivity of HIV-1. J Virol 2012, 86:2533-2544.

44. Yung E, Sorin M, Wang EJ, Perumal S, Ott D, Kalpana GV: Specificity of interaction of INI1/hSNF5 with retroviral integrases and its functional significance. J Virol 2004, 78:2222-2231.

45. Sorin M, Yung E, Wu X, Kalpana GV: HIV-1 replication in cell lines harboring INI1/hSNF5 mutations. Retrovirology 2006, 3:56.

46. Sorin M, Cano J, Das S, Mathew S, Wu X, Davies KP, Shi X, Cheng SW, Ott D, Kalpana GV: Recruitment of a SAP18-HDAC1 complex into HIV-1 virions and its requirement for viral replication. PLoS Pathog 2009, 5:e1000463.

47. Lesbats P, Botbol Y, Chevereau G, Vaillant C, Calmels C, Arneodo A, Andreola $M L$, Lavigne M, Parissi V: Functional coupling between HIV-1 integrase and the SWI/SNF chromatin remodeling complex for efficient in vitro integration into stable nucleosomes. PLoS Pathog 2011, 7:e1001280.

48. Luban J: Cyclophilin A, TRIM5, and resistance to human immunodeficiency virus type 1 infection. J Virol 2007, 81:1054-1061.

49. Briones MS, Dobard CW, Chow SA: Role of human immunodeficiency virus type 1 integrase in uncoating of the viral core. J Virol 2010, 84:5181-5190.

50. Sheehy AM, Gaddis NC, Malim MH: The antiretroviral enzyme APOBEC3G is degraded by the proteasome in response to HIV-1 Vif. Nat Med 2003, 9:1404-1407.

51. Zheng YH, Irwin D, Kurosu T, Tokunaga K, Sata T, Peterlin BM: Human APOBEC3F is another host factor that blocks human immunodeficiency virus type 1 replication. J Virol 2004, 78:6073-6076.

52. Zennou V, Perez-Caballero D, Gottlinger H, Bieniasz PD: APOBEC3G incorporation into human immunodeficiency virus type 1 particles. J Virol 2004, 78:12058-12061.

53. Malim MH: APOBEC proteins and intrinsic resistance to HIV-1 infection. Philos Trans R Soc Lond B Biol Sci 2009, 364:675-687.

54. Arhel N: Revisiting HIV-1 uncoating. Retrovirology 2010, 7:96.

55. Segura MM, Garnier A, Di Falco MR, Whissell G, Meneses-Acosta A, Arcand $\mathrm{N}$, Kamen A: Identification of host proteins associated with retroviral vector particles by proteomic analysis of highly purified vector preparations. J Virol 2008, 82:1107-1117.

56. Stephenson ST, Bostik P, Song B, Rajan D, Bhimani S, Rehulka P, Mayne AE, Ansari AA: Distinct host cell proteins incorporated by SIV replicating in CD4+ T cells from natural disease resistant versus non-natural disease susceptible hosts. Retrovirology 2010, 7:107.

57. Konig R, Zhou Y, Elleder D, Diamond TL, Bonamy GM, Irelan JT, Chiang CY, Tu BP, De Jesus PD, Lilley CE, et al: Global analysis of host-pathogen interactions that regulate early-stage HIV-1 replication. Cell 2008, 135: 49-60.

58. Brass AL, Dykxhoorn DM, Benita Y, Yan N, Engelman A, Xavier RJ, Lieberman J, Elledge SJ: Identification of host proteins required for HIV infection through a functional genomic screen. Science 2008, 319:921-926.

59. Zhou H, Xu M, Huang Q, Gates AT, Zhang XD, Castle JC, Stec E, Ferrer M, Strulovici B, Hazuda DJ, Espeseth AS: Genome-scale RNAi screen for host factors required for HIV replication. Cell Host Microbe 2008, 4:495-504.
60. Travers SA, Tully DC, McCormack GP, Fares MA: A study of the coevolutionary patterns operating within the env gene of the HIV-1 group M subtypes. Mol Biol Evol 2007, 24:2787-2801.

61. Basheeruddin K, Rechtoris C, Mazzone T: Evaluation of the role of Ap1-like proteins in the enhanced apolipoprotein E gene transcription accompanying phorbol ester induced macrophage differentiation. Biochim Biophys Acta 1994, 1218:235-241.

62. Schwende $H$, Fitzke $E$, Ambs $P$, Dieter P. Differences in the state of differentiation of THP-1 cells induced by phorbol ester and 1,25dihydroxyvitamin D3. J Leukoc Biol 1996, 59:555-561.

63. Kewalramani VN, Emerman $\mathrm{M}: \mathrm{Vpx}$ association with mature core structures of HIV-2. Virology 1996, 218:159-168.

64. Kotov A, Zhou J, Flicker P, Aiken C: Association of Nef with the human immunodeficiency virus type 1 core. J Virol 1999, 73:8824-8830.

65. Aiken C: Cell-free assays for HIV-1 uncoating. Methods Mol Biol 2009, 485:41-53.

66. Shah VB, Aiken C: In vitro uncoating of HIV-1 cores. J Vis Exp 2011, (57):e3384

67. Yu X, Matsuda Z, Yu QC, Lee TH, Essex M: Vpx of simian immunodeficiency virus is localized primarily outside the virus core in mature virions. I Virol 1993, 67:4386-4390.

68. Liu H, Wu X, Newman M, Shaw GM, Hahn BH, Kappes JC: The Vif protein of human and simian immunodeficiency viruses is packaged into virions and associates with viral core structures. J Virol 1995, 69:7630-7638.

69. Gluschankof P, Mondor I, Gelderblom HR, Sattentau QJ: Cell membrane vesicles are a major contaminant of gradient-enriched human immunodeficiency virus type-1 preparations. Virology 1997, 230:125-133.

70. Trubey CM, Chertova E, Coren LV, Hilburn JM, Hixson CV, Nagashima K, Lifson JD, Ott DE: Quantitation of HLA class II protein incorporated into human immunodeficiency type 1 virions purified by anti-CD45 immunoaffinity depletion of microvesicles. J Virol 2003, 77:12699-12709.

71. Abdelhaleem MM, Hameed S, Klassen D, Greenberg AH: Leukophysin: an RNA helicase A-related molecule identified in cytotoxic T cell granules and vesicles. J Immunol 1996, 156:2026-2035.

72. Bolinger C, Sharma A, Singh D, Yu L, Boris-Lawrie K: RNA helicase A modulates translation of HIV-1 and infectivity of progeny virions. Nucleic Acids Res 2010, 38:1686-1696.

73. Xing L, Liang C, Kleiman L: Coordinate roles of Gag and RNA helicase A in promoting the annealing of formula to HIV-1 RNA. J Virol 2011, 85: 1847-1860.

74. Bushman FD, Malani N, Fernandes J, D'Orso I, Cagney G, Diamond TL, Zhou H, Hazuda DJ, Espeseth AS, Konig R, et al: Host cell factors in HIV replication: meta-analysis of genome-wide studies. PLOS Pathog 2009, 5: e1000437.

75. Jager S, Cimermancic P, Gulbahce N, Johnson JR, McGovern KE, Clarke SC, Shales M, Mercenne G, Pache L, Li K, et al: Global landscape of HIV-human protein complexes. Nature 2012, 481:365-370

76. Rhee SS, Hunter E: Structural role of the matrix protein of type D retroviruses in gag polyprotein stability and capsid assembly. J Virol 1990, 64:4383-4389.

77. Rhee SS, Hunter E: Amino acid substitutions within the matrix protein of type $D$ retroviruses affect assembly, transport and membrane association of a capsid. EMBO J 1991, 10:535-546.

78. Bukrinsky MI, Haggerty S, Dempsey MP, Sharova N, Adzhubel A, Spitz L, Lewis $\mathrm{P}$, Goldfarb D, Emerman M, Stevenson M: A nuclear localization signal within HIV-1 matrix protein that governs infection of non-dividing cells. Nature 1993, 365:666-669.

79. Mannioui A, Nelson E, Schiffer C, Felix N, Le Rouzic E, Benichou S, Gluckman JC, Canque B: Human immunodeficiency virus type 1 KK26-27 matrix mutants display impaired infectivity, circularization and integration but not nuclear import. Virology 2005, 339:21-30.

80. Yu X, Yuan X, Matsuda Z, Lee TH, Essex M: The matrix protein of human immunodeficiency virus type 1 is required for incorporation of viral envelope protein into mature virions. J Virol 1992, 66:4966-4971.

81. Dorfman T, Mammano F, Haseltine WA, Gottlinger HG: Role of the matrix protein in the virion association of the human immunodeficiency virus type 1 envelope glycoprotein. J Virol 1994, 68:1689-1696.

82. Checkley MA, Luttge BG, Freed EO: HIV-1 envelope glycoprotein biosynthesis, trafficking, and incorporation. J Mol Biol 2011, 410:582-608

83. Qi M, Aiken C: Selective restriction of Nef-defective human immunodeficiency virus type 1 by a proteasome-dependent mechanism. J Virol 2007, 81:1534-1536. 
84. Qi M, Aiken C: Nef enhances HIV-1 infectivity via association with the virus assembly complex. Virology 2008, 373:287-297.

85. Syed F, McCrae MA: Interactions in vivo between the Vif protein of HIV-1 and the precursor ( $\operatorname{Pr55}(\mathrm{GAG}))$ of the virion nucleocapsid proteins. Arch Virol 2009, 154:1797-1805.

86. Cohen EA, Dehni G, Sodroski JG, Haseltine WA: Human immunodeficiency virus vpr product is a virion-associated regulatory protein. J Virol 1990 64:3097-3099

87. Lu YL, Spearman P, Ratner L: Human immunodeficiency virus type 1 viral protein R localization in infected cells and virions. J Virol 1993, 67: 6542-6550.

88. Paxton W, Connor Rl, Landau NR: Incorporation of Vpr into human immunodeficiency virus type 1 virions: requirement for the $\mathrm{p} 6$ region of gag and mutational analysis. J Virol 1993, 67:7229-7237.

89. Heinzinger NK, Bukinsky Ml, Haggerty SA, Ragland AM, Kewalramani V, Lee MA, Gendelman HE, Ratner L, Stevenson M, Emerman M: The Vpr protein of human immunodeficiency virus type 1 influences nuclear localization of viral nucleic acids in nondividing host cells. Proc Natl Acad Sci USA 1994, 91:7311-7315.

90. Popov S, Rexach M, Zybarth G, Reiling N, Lee MA, Ratner L, Lane CM, Moore MS, Blobel G, Bukrinsky M: Viral protein R regulates nuclear import of the HIV-1 pre-integration complex. EMBO J 1998, 17:909-917.

91. Vodicka MA, Koepp DM, Silver PA, Emerman M: HIV-1 Vpr interacts with the nuclear transport pathway to promote macrophage infection. Genes Dev 1998, 12:175-185.

92. Le Douce V, Herbein G, Rohr O, Schwartz C: Molecular mechanisms of HIV1 persistence in the monocyte-macrophage lineage. Retrovirology 2010, 7:32.

93. Martin-Serrano J, Neil SJ: Host factors involved in retroviral budding and release. Nat Rev Microbiol 2011, 9:519-531.

94. Ott DE, Coren LV, Kane BP, Busch LK, Johnson DG, Sowder RC 2nd, Chertova EN, Arthur LO, Henderson LE: Cytoskeletal proteins inside human immunodeficiency virus type 1 virions. J Virol 1996, 70:7734-7743.

95. Jeang KT, Yedavalli V: Role of RNA helicases in HIV-1 replication. Nucleic Acids Res 2006, 34:4198-4205.

96. Chai W, Ford LP, Lenertz L, Wright WE, Shay JW: Human Ku70/80 associates physically with telomerase through interaction with hTERT. $J$ Biol Chem 2002, 277:47242-47247.

97. Pfingsten JS, Goodrich KJ, Taabazuing C, Ouenzar F, Chartrand P, Cech TR: Mutually exclusive binding of telomerase RNA and DNA by ku alters telomerase recruitment model. Cell 2012, 148:922-932.

98. Grigoletto A, Lestienne P, Rosenbaum J: The multifaceted proteins Reptin and Pontin as major players in cancer. Biochim Biophys Acta 2011, 1815:147-157.

99. Humphries JD, Byron A, Bass MD, Craig SE, Pinney JW, Knight D Humphries MJ: Proteomic analysis of integrin-associated complexes identifies RCC2 as a dual regulator of Rac1 and Arf6. Sci Signal 2009, 2:ra51.

100. Beddow AL, Richards SA, Orem NR, Macara IG: The Ran/TC4 GTPasebinding domain: identification by expression cloning and characterization of a conserved sequence motif. Proc Natl Acad Sci USA 1995, 92:3328-3332.

101. Kehlenbach RH, Dickmanns A, Kehlenbach A, Guan T, Gerace L: A role for RanBP1 in the release of CRM1 from the nuclear pore complex in a terminal step of nuclear export. J Cell Biol 1999, 145:645-657.

102. Ishaq M, Hu J, Wu X, Fu Q, Yang Y, Liu Q, Guo D: Knockdown of cellular RNA helicase DDX3 by short hairpin RNAs suppresses HIV-1 viral replication without inducing apoptosis. Mol Biotechnol 2008, 39:231-238.

103. Yedavalli VS, Neuveut C, Chi YH, Kleiman L, Jeang KT: Requirement of DDX3 DEAD box RNA helicase for HIV-1 Rev-RRE export function. Cell 2004, 119:381-392.

104. Li J, Tang H, Mullen TM, Westberg C, Reddy TR, Rose DW, Wong-Staal F: A role for RNA helicase A in post-transcriptional regulation of HIV type 1. Proc Natl Acad Sci USA 1999, 96:709-714.

105. Levesque K, Halvorsen M, Abrahamyan L, Chatel-Chaix L, Poupon V, Gordon H, DesGroseillers L, Gatignol A, Mouland AJ: Trafficking of HIV-1 RNA is mediated by heterogeneous nuclear ribonucleoprotein A2 expression and impacts on viral assembly. Traffic 2006, 7:1177-1193.

106. Okunola HL, Krainer AR: Cooperative-binding and splicing-repressive properties of hnRNP A1. Mol Cell Biol 2009, 29:5620-5631.
107. Marchand V, Santerre M, Aigueperse C, Fouillen L, Saliou JM, Van Dorsselaer A, Sanglier-Cianferani S, Branlant C, Motorin Y: Identification of protein partners of the human immunodeficiency virus 1 tat/rev exon 3 leads to the discovery of a new HIV-1 splicing regulator, protein hnRNP K. RNA Biol 2011, 8:325-342

108. Ajamian L, Abrahamyan L, Milev M, Ivanov PV, Kulozik AE, Gehring NH Mouland AJ: Unexpected roles for UPF1 in HIV-1 RNA metabolism and translation. RNA 2008, 14:914-927.

109. Liu B, Dai R, Tian CJ, Dawson L, Gorelick R, Yu XF: Interaction of the human immunodeficiency virus type 1 nucleocapsid with actin. J Virol 1999, 73:2901-2908

110. Arhel N, Genovesio A, Kim KA, Miko S, Perret E, Olivo-Marin JC, Shorte S, Charneau P: Quantitative four-dimensional tracking of cytoplasmic and nuclear HIV-1 complexes. Nat Methods 2006, 3:817-824.

111. Jolly C, Mitar I, Sattentau QJ: Requirement for an intact T-cell actin and tubulin cytoskeleton for efficient assembly and spread of human immunodeficiency virus type 1. J Virol 2007, 81:5547-5560.

112. Lehmann M, Milev MP, Abrahamyan L, Yao XJ, Pante N, Mouland AJ: Intracellular transport of human immunodeficiency virus type 1 genomic RNA and viral production are dependent on dynein motor function and late endosome positioning. J Biol Chem 2009, 284:14572-14585.

113. Welch MD, Mullins RD: Cellular control of actin nucleation. Annu Rev Cell Dev Biol 2002, 18:247-288.

114. Komano J, Miyauchi K, Matsuda Z, Yamamoto N: Inhibiting the Arp2/3 complex limits infection of both intracellular mature vaccinia virus and primate lentiviruses. Mol Biol Cell 2004, 15:5197-5207.

115. Christ F, Thys W, De Rijck J, Gijsbers R, Albanese A, Arosio D, Emiliani S, Rain JC, Benarous R, Cereseto A, Debyser Z: Transportin-SR2 imports HIV into the nucleus. Curr Biol 2008, 18:1192-1202.

116. Krishnan L, Matreyek KA, Oztop I, Lee K, Tipper CH, Li X, Dar MJ, Kewalramani VN, Engelman A: The requirement for cellular transportin 3 (TNPO3 or TRN-SR2) during infection maps to human immunodeficiency virus type 1 capsid and not integrase. J Virol 2010, 84:397-406.

117. Logue EC, Taylor KT, Goff PH, Landau NR: The cargo-binding domain of transportin 3 is required for lentivirus nuclear import. J Virol 2011 85:12950-12961.

118. Gallay P, Hope T, Chin D, Trono D: HIV-1 infection of nondividing cells through the recognition of integrase by the importin/karyopherin pathway. Proc Natl Acad Sci USA 1997, 94:9825-9830.

119. Armon-Omer A, Graessmann A, Loyter A: A synthetic peptide bearing the HIV-1 integrase 161-173 amino acid residues mediates active nuclear import and binding to importin alpha: characterization of a functional nuclear localization signal. J Mol Biol 2004, 336:1117-1128.

120. Bouyac-Bertoia M, Dvorin JD, Fouchier RA, Jenkins Y, Meyer BE, Wu LI, Emerman M, Malim MH: HIV-1 infection requires a functional integrase NLS. Mol Cell 2001, 7:1025-1035.

121. Hearps AC, Jans DA: HIV-1 integrase is capable of targeting DNA to the nucleus via an importin alpha/beta-dependent mechanism. Biochem $J$ 2006, 398:475-484.

122. Askjaer P, Bachi A, Wilm M, Bischoff FR, Weeks DL, Ogniewski V, Ohno M, Niehrs C, Kjems J, Mattaj IW, Fornerod M: RanGTP-regulated interactions of CRM1 with nucleoporins and a shuttling DEAD-box helicase. Mol Cell Biol 1999, 19:6276-6285.

123. Murray JL, Mavrakis M, McDonald NJ, Yilla M, Sheng J, Bellini WJ, Zhao L, Le Doux JM, Shaw MW, Luo CC, et al: Rab9 GTPase is required for replication of human immunodeficiency virus type 1, filoviruses, and measles virus. J Virol 2005, 79:11742-11751.

124. Stutz F, Izaurralde E, Mattaj IW, Rosbash M: A role for nucleoporin FG repeat domains in export of human immunodeficiency virus type $1 \mathrm{Rev}$ protein and RNA from the nucleus. Mol Cell Biol 1996, 16:7144-7150.

125. Strack B, Calistri A, Craig S, Popova E, Gottlinger HG: AIP1/ALIX is a binding partner for HIV-1 p6 and EIAV p9 functioning in virus budding. Cell 2003, 114:689-699.

126. Fukushi M, Dixon J, Kimura T, Tsurutani N, Dixon MJ, Yamamoto N: Identification and cloning of a novel cellular protein Naf1, Nefassociated factor 1 , that increases cell surface CD4 expression. FEBS Lett 1999, 442:83-88.

127. Gurer C, Berthoux L, Luban J: Covalent modification of human immunodeficiency virus type 1 p6 by SUMO-1. J Virol 2005, 79:910-917. 
128. Agostini I, Popov S, Li J, Dubrovsky L, Hao T, Bukrinsky M: Heat-shock protein 70 can replace viral protein R of HIV-1 during nuclear import of the viral preintegration complex. Exp Cell Res 2000, 259:398-403.

129. Iordanskiy S, Zhao Y, DiMarzio P, Agostini I, Dubrovsky L, Bukrinsky M: Heatshock protein 70 exerts opposing effects on Vpr-dependent and Vprindependent HIV-1 replication in macrophages. Blood 2004, 104: 1867-1872.

130. von Schwedler UK, Stuchell M, Muller B, Ward DM, Chung HY, Morita E, Wang HE, Davis T, He GP, Cimbora DM, et al: The protein network of HIV budding. Cell 2003, 114:701-713.

131. Benaroch P, Billard E, Gaudin R, Schindler M, Jouve M: HIV-1 assembly in macrophages. Retrovirology 2010, 7:29.

132. Pelchen-Matthews A, Kramer B, Marsh M: Infectious HIV-1 assembles in late endosomes in primary macrophages. J Cell Biol 2003, 162:443-455.

133. Deneka M, Pelchen-Matthews A, Byland R, Ruiz-Mateos E, Marsh M: In macrophages, HIV-1 assembles into an intracellular plasma membrane domain containing the tetraspanins CD81, CD9, and CD53. J Cell Biol 2007, 177:329-341.

134. Gousset K, Ablan SD, Coren LV, Ono A, Soheilian F, Nagashima K, Ott DE, Freed EO: Real-time visualization of HIV-1 GAG trafficking in infected macrophages. PLoS Pathog 2008, 4:e1000015.

135. Bennett AE, Narayan K, Shi D, Hartnell LM, Gousset K, He H, Lowekamp BC, Yoo TS, Bliss D, Freed EO, Subramaniam S: Ion-abrasion scanning electron microscopy reveals surface-connected tubular conduits in HIV-infected macrophages. PLoS Pathog 2009, 5:e1000591.

136. Usami Y, Popov S, Gottlinger HG: Potent rescue of human immunodeficiency virus type 1 late domain mutants by ALIX/AIP1 depends on its CHMP4 binding site. J Virol 2007, 81:6614-6622.

137. Ott DE: Potential roles of cellular proteins in HIV-1. Rev Med Virol 2002 12:359-374.

138. Sasaki H, Ozaki H, Karaki H, Nonomura Y: Actin filaments play an essential role for transport of nascent HIV-1 proteins in host cells. Biochem Biophys Res Commun 2004, 316:588-593.

139. Kostenko S, Moens U: Heat shock protein 27 phosphorylation: kinases, phosphatases, functions and pathology. Cell Mol Life Sci 2009, 66: 3289-3307.

140. Burston SG, Clarke AR: Molecular chaperones: physical and mechanistic properties. Essays Biochem 1995, 29:125-136.

141. Mayer MP: Gymnastics of molecular chaperones. Mol Cell 2010, 39: 321-331.

142. Shi $Y$, Reddy B, Manley JL: PP1/PP2A phosphatases are required for the second step of Pre-mRNA splicing and target specific snRNP proteins. Mol Cell 2006, 23: 819-829.

143. Weber G, Cristao VF, De LAF, Santos KF, Holton N, Rappsilber J, Beggs JD, Wahl MC: Mechanism for Aar2p function as a U5 snRNP assembly factor. Genes Dev 2011, 25:1601-1612.

144. Torreira E, Jha S, Lopez-Blanco JR, Arias-Palomo E, Chacon P, Canas C, Ayora S, Dutta A, Llorca O: Architecture of the pontin/reptin complex, essential in the assembly of several macromolecular complexes. Structure 2008, 16:1511-1520

145. Li L, Olvera JM, Yoder KE, Mitchell RS, Butler SL, Lieber M, Martin SL, Bushman FD: Role of the non-homologous DNA end joining pathway in the early steps of retroviral infection. EMBO J 2001, 20:3272-3281.

146. Jeanson L, Subra F, Vaganay S, Hervy M, Marangoni E, Bourhis J, Mouscadet JF: Effect of Ku80 depletion on the preintegrative steps of HIV-1 replication in human cells. Virology 2002, 300:100-108.

147. Martin-Serrano J: The role of ubiquitin in retroviral egress. Traffic 2007, 8:1297-1303.

148. Jager S, Gottwein E, Krausslich HG: Ubiquitination of human immunodeficiency virus type $1 \mathrm{Gag}$ is highly dependent on Gag membrane association. J Virol 2007, 81:9193-9201.

149. Westervelt P, Trowbridge DB, Epstein LG, Blumberg BM, Li Y, Hahn BH, Shaw GM, Price RW, Ratner L: Macrophage tropism determinants of human immunodeficiency virus type 1 in vivo. J Virol 1992, 66:2577-2582.
150. O'Doherty U, Swiggard WJ, Malim MH: Human immunodeficiency virus type 1 spinoculation enhances infection through virus binding. J Virol 2000, 74:10074-10080.

151. Formolo CA, Mintz M, Takanohashi A, Brown KJ, Vanderver A, Halligan B, Hathout Y: Time series proteome profiling. Methods Mol Biol 2011, 694:365-377.

152. Butler SL, Hansen MS, Bushman FD: A quantitative assay for HIV DNA integration in vivo. Nat Med 2001, 7:631-634

doi:10.1186/1742-4690-9-65

Cite this article as: Santos et al:: Virus-producing cells determine the host protein profiles of HIV-1 virion cores. Retrovirology 2012 9:65.

\section{Submit your next manuscript to BioMed Central and take full advantage of:}

- Convenient online submission

- Thorough peer review

- No space constraints or color figure charges

- Immediate publication on acceptance

- Inclusion in PubMed, CAS, Scopus and Google Scholar

- Research which is freely available for redistribution

Submit your manuscript at www.biomedcentral.com/submit
C Biomed Central 